\title{
Synthesis of Perhydrofuro[2,3-b]furans from Isopentenyl Alcohol through Carbonyl-ene and Wacker-type Reactions
}

\author{
Francisco Alonso, ${ }^{*[a]}$ Mamen Rodríguez-Fernández, ${ }^{[a]}$ Daniel Sánchez, ${ }^{[\mathrm{a}]}$ and Miguel Yus ${ }^{[\mathrm{a}]}$
}

Dedicated to Professor K. C. Nikolaou on the occasion of his 65th birthday

Keywords: Lewis acids / Ene reaction / Oxidation / Wacker / Perhydrofurofurans

A range of 2-substituted perhydrofuro[2,3-b]furans has been synthesised in a stereoselective manner through a sequence including the Lewis-acid catalysed carbonyl-ene reaction of protected isopentenyl alcohol with a variety of enophiles, deprotection of the corresponding monoprotected diols, and palladium-catalysed intramolecular acetalisation under Wackertype reaction conditions. (@ WILEY-VCH Verlag GmbH \& Co. KGaA, 69451 Weinheim, Germany, 2011) [a] Departamento de Química Orgánica, Facultad de Ciencias and Instituto de Síntesis Orgánica (ISO), Universidad de Alicante, Apdo. 99, E-03080 Alicante, Spain

Fax: +34-965903549

E-mail: falonso@ua.es

\section{Introduction}

Perhydrofuro[2,3-b]furans possess an interesting bicyclic acetal structure which is present in many natural products. ${ }^{[1]}$ In particular, those substituted at the 2-position can be found as substructures in neo-clerodane diterpenes, which are especially abundant in Ajuga ${ }^{[2]}$ and Scutellaria ${ }^{[3]}$ species. Lupulin C $(\mathbf{I}),{ }^{[2 a]}$ scutecolumnin $\mathrm{C}$ (II) ${ }^{[3 \mathrm{a}]}$ and areptin $\mathrm{A}^{[2 \mathrm{c}]}$ are some representative examples of this family of natural products (Figure 1), which exhibit notable insect antifeedant activity. $^{[4]}$ Compounds $\mathbf{I V}$ and $\mathbf{V}$ are synthetic analogues, with the latter displaying the above mentioned activity in laboratory bioassays. ${ }^{[5]}$ The reported synthetic routes toward this type of compounds are, however, rather long. ${ }^{[4-6]}$ Therefore, the design of alternative approaches to attain 2-substituted perhydrofuro[2,3-b]furans in a straight manner would be welcome.

Our continuous interest in the synthesis of fused bicyclic ${ }^{[7]}$ and spirocyclic ${ }^{[8]}$ polyether skeletons, led us to the discovery of a new and highly efficient synthesis of 2,5-substituted perhydrofuro[2,3$b$ ]furans. The strategy consisted of the arene-catalysed lithiation of allylic chlorinated substrates and subsequent reaction with carbonyl compounds, followed by an intramolecular acetalisation of the resulting 3-methylidene-1,5-diols under Wacker-type reaction conditions. ${ }^{[9]}$ More recently, we have developed a new synthesis of 2 -substituted perhydrofuro[2,3-b]furans based on the ultrasoundpromoted generation of the dianion of isopentenyl alcohol and reaction with carbonyl compounds, followed by the aforementioned intramolecular acetalisation. ${ }^{[10]}$ The methodology was applied both to ketones and aldehydes, with the perhydrofuro[2,3- $b]$ furans arising from the latter being obtained stereoselectively (Scheme 1). Although the overall yields were modest, this approach represents, to the best of our knowledge, the most direct route to this kind of compounds reported hitherto. In addition, their transformation into the corresponding lactones was easily accomplished by ruthenium-catalysed oxidation.

Notwithstanding the advantages of this methodology, all the perhydrofurofurans synthesised bore hydrocarbon substituents due to the incompatibility of the dianion of isopentenyl alcohol with

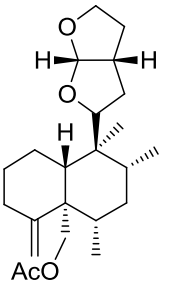

lupulin C (I)

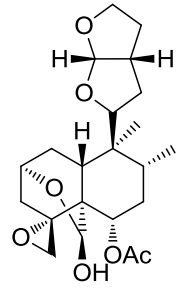

scutecolumnin C (II)

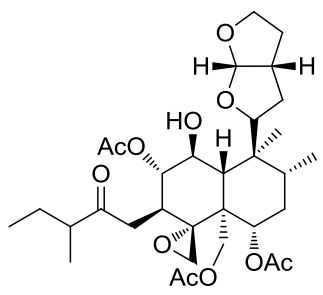

areptin A (III)<smiles>CC(C)(C)[C@@H]1C[C@H]2CCO[C@H]2O1</smiles>

IV

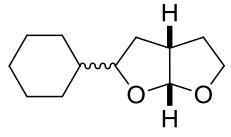

Figure 1. Natural and synthetic 2-substituted perhydrofuro[2,3-b]furans.
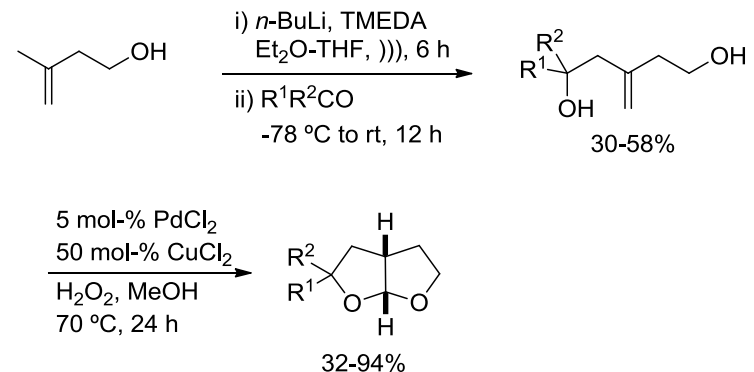

$\mathrm{R}^{1} \mathrm{R}^{2} \mathrm{CO}=\mathrm{Et}_{2} \mathrm{CO},\left(\mathrm{CH}_{2}\right)_{5} \mathrm{CO}, \mathrm{Ph}_{2} \mathrm{CO}, n-\mathrm{BuCHO}, c-\mathrm{C}_{6} \mathrm{H}_{11} \mathrm{CHO}, \mathrm{PhCHO}$

Scheme 1. Straightforward synthesis of perhydrofuro[2,3-b]furans through the isopentenyl alcohol dianion and Wacker-type reaction. 
many functional groups. We sought to synthesise more functionalised methylidenic 1,5-diols, and we identified the carbonyl-ene reaction as a potential solution. This is an atomefficient carbon-carbon bond forming reaction, alternative to the carbonyl addition of allylmetals, in which an alkene bearing an allylic hydrogen (the ene) reacts with a carbonyl compound (the enophile), accompanied by migration of the double bond and a 1,5hydrogen shift. ${ }^{[1]}$ The intermolecular version is entropically disfavoured with respect to the intramolecular counterpart and hence the carbonyl group needs to be highly activated. Lewis acid promoters, such as aluminium halides, and catalysts, such as $\mathrm{SnCl}_{4}$, $\mathrm{BF}_{3} \cdot \mathrm{OEt}_{2}, \mathrm{Sc}(\mathrm{OTf})_{3}$ or $\mathrm{Yb}(\mathrm{OTf})_{3}$, enable the ene reactions to proceed at room or low temperature. Most of the research concerning intermolecular processes is focussed on nonfunctionalised hydrocarbon-based enes. ${ }^{[12]}$ Few reports deal with protected methallyl alcohol as the ene component, ${ }^{[13]}$ whereas the carbonyl-ene reaction with isopentenyl alcohol has been seldom studied. ${ }^{[14]}$ We wish to present herein a new and straight route towards the synthesis of functionalised 2-substituted perhydrofuro[2,3-b]furans involving the carbonyl-ene reaction of protected isopentenyl alcohol with activated enophiles, followed by deprotection and oxidation-acetalisation under Wacker-type ${ }^{[15]}$ reaction conditions.

\section{Results and Discussion}

Initial attempts to directly react isopentenol with either paraformaldehyde or ethyl glyoxylate, in the presence of variable amounts of different Lewis acids, led to complex mixtures and/or to the starting material. A maximum $20 \%$ conversion into the desired homoallylic diol was recorded for the reaction with ethyl glyoxylate promoted by $\mathrm{SnCl}_{4}$ (1 equiv.) at $-78{ }^{\circ} \mathrm{C}$ after $72 \mathrm{~h}$. Therefore, we decided that it was more convenient to carry out all the ene reactions with protected isopentenol as the $t$ butyldimethylsilyl ether $\mathbf{1}$. Unfortunately, we could not find a Lewis acid that might be generally applied to a range of enophiles. Consequently, a selection of the Lewis acid and optimisation of the reaction conditions was mandatory for every enophile studied.

Table 1. Carbonyl-ene reaction of $\mathbf{1}$ with paraformaldehyde (2a).

\begin{tabular}{|c|c|c|c|c|c|}
\hline & OTBDMS + & $\begin{array}{l}\mathrm{CHO})_{n} \\
2 a\end{array}$ & $\underset{\mathrm{CH}_{2} \mathrm{Cl}_{2}}{\stackrel{\text { Lewis acid }}{\longrightarrow}}$ & & $3 a$ \\
\hline Entry & $\begin{array}{l}\text { Lewis acid } \\
\text { [mol-\%] }\end{array}$ & $\begin{array}{l}\mathbf{1 / 2 a} \\
{[\mathrm{mmol}]}\end{array}$ & $\begin{array}{l}\mathrm{T} \\
{\left[{ }^{\circ} \mathrm{C}\right]}\end{array}$ & $\begin{array}{l}t \\
{[\mathrm{~h}]}\end{array}$ & $\begin{array}{l}\text { Product } \\
{[\%]^{[a]}}\end{array}$ \\
\hline 1 & $\mathrm{BF}_{3} \cdot \mathrm{Et}_{2} \mathrm{O}$ [119] & $1: 1$ & -10 & 3.5 & $1[56]^{[b]}$ \\
\hline 2 & $\mathrm{BF}_{3} \cdot \mathrm{Et}_{2} \mathrm{O}[119]$ & $1: 1$ & -10 & 5 & $\mathbf{1}[9], \mathbf{3 a}[13]^{[\mathrm{b}]}$ \\
\hline 3 & $\mathrm{BF}_{3} \cdot \mathrm{Et}_{2} \mathrm{O}[119]$ & $1: 1$ & 0 & 3 & $\mathbf{3 a}[46]^{[b]}$ \\
\hline 4 & $\mathrm{Cu}(\mathrm{OTf})_{2}[10]$ & $1: 10$ & r.t. & 24 & 1 [95] \\
\hline 5 & $\mathrm{TiCl}_{4}[10]$ & $1: 1$ & -70 to -30 & 48 & $\mathbf{1}[94], \mathbf{3 a}[6]$ \\
\hline 6 & $\mathrm{SnCl}_{4}[100]$ & $2: 1$ & -78 & 16 & $\mathbf{1}$ [79], $\mathbf{3 a}$ [2] \\
\hline 7 & $\mathrm{AlCl}_{3}[150]$ & $1: 1$ & 0 & 24 & $\mathbf{1}[73], \mathbf{3 a}[26]$ \\
\hline 8 & $\mathrm{Me}_{2} \mathrm{AlCl}[220]$ & $1: 1$ & 0 to r.t. & 16 & 3a [91] (72) \\
\hline
\end{tabular}

[a] Determined from the GLC peak area, isolated yield in parenthesis. [b] Substantial amounts of by-products were obtained.

Paraformaldehyde has been one of the most studied enophiles with hydrocarbon enes, generally giving modest yield of the homoallylic alcohols. ${ }^{[16]}$ To the best of our knowledge, there is only one example in the literature that reports its reaction with isopentenyl alcohol which, in the presence of $\mathrm{Me}_{2} \mathrm{AlCl}$, led to a mixture of three products. ${ }^{[17]} \mathrm{We}$ observed that $\mathrm{BF}_{3} \cdot \mathrm{Et}_{2} \mathrm{O}$ at $0{ }^{\circ} \mathrm{C}$ gave the expected product in moderate conversion, although substantial amounts of by-products were also present irrespective of the reaction conditions (Table 1, entries 1-3). Catalytic $\mathrm{Cu}(\mathrm{OTf})_{2}$ and $\mathrm{TiCl}_{4}$ or stoichiometric $\mathrm{SnCl}_{4}$ and $\mathrm{AlCl}_{3}$ exerted very little effect, albeit a ca. $25 \%$ conversion was observed with the latter (Table 1, entries 4-7). We were delighted with the performance of the organoaluminium Lewis acid $\mathrm{Me}_{2} \mathrm{AlCl}$, which provided high conversion and good isolated yield of the desired product (Table 1, entry 8 ).

We next studied the behaviour of 2-oxoesters as the enophiles, starting with ethyl glyoxylate (2b). In this case, either $\mathrm{TiCl}_{4}$ or $\mathrm{Me}_{2} \mathrm{AlCl}$ gave low conversions into $\mathbf{3 b}$ (Table 2, entries 1 and 2). The $\mathrm{AgSbF}_{6} /$ rac-BINAP-PdCl ${ }_{2}$ combination, which proved to be effective in the asymmetric version of the glyoxylate- and phenylglyoxal-ene reaction with hydrocarbon enes, ${ }^{[18]}$ furnished the expected product in moderate conversion, independently of the temperature and reaction time (Table 2, entries 3 and 4). In contrast, $\mathrm{SnCl}_{4}$ gave more satisfactory results; catalytic amounts of the Lewis acid led to moderate conversions and by-product formation (Table 2, entries 5 and 6). The reaction outcome was, however, especially good with stoichiometric amounts at low temperature and prolonged time (Table 2, entries 7 and 8).

Table 2. Carbonyl-ene reaction of $\mathbf{1}$ with ethyl glyoxylate (2b).

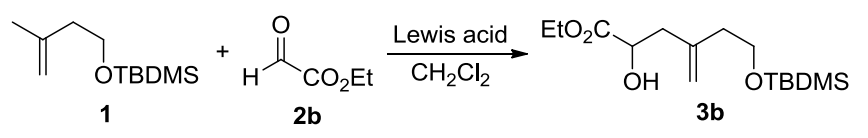

\begin{tabular}{|c|c|c|c|c|c|}
\hline Entry & $\begin{array}{l}\text { Lewis acid } \\
{[\mathrm{mol} \%]}\end{array}$ & $\begin{array}{l}\mathbf{1} / \mathbf{2 b} \\
{[\mathrm{mmol}]}\end{array}$ & $\begin{array}{l}\mathrm{T} \\
{\left[{ }^{\circ} \mathrm{C}\right]}\end{array}$ & $\begin{array}{l}t \\
{[\mathrm{~h}]}\end{array}$ & $\begin{array}{l}\text { Product } \\
{[\%]^{[\mathrm{a}]}}\end{array}$ \\
\hline 1 & $\mathrm{TiCl}_{4}[10]$ & $1: 1$ & -70 to -30 & 24 & $\mathbf{1}[89], \mathbf{3 b}[11]$ \\
\hline 2 & $\mathrm{Me}_{2} \mathrm{AlCl}[220]$ & $1: 1$ & 0 to r.t. & 27 & $\mathbf{1}[65], \mathbf{3 b}[35]$ \\
\hline 3 & $\begin{array}{l}\mathrm{AgSbF}_{6}[11], \\
\text { BINAP-PdCl } \\
25]\end{array}$ & $1: 2.2$ & -78 & 3.5 & $\mathbf{1}[42], \mathbf{3 b}[58]$ \\
\hline 4 & $\begin{array}{l}\mathrm{AgSbF}_{6}[11], \\
\text { BINAP-PdCl }_{2}[5]\end{array}$ & $1: 1$ & r.t. & 31 & $\mathbf{1}[60], \mathbf{3 b}[40]$ \\
\hline 5 & $\mathrm{SnCl}_{4}[10]$ & $1: 1$ & r.t. & 32 & $\mathbf{3 b}[60]^{[\mathrm{b}]}$ \\
\hline 6 & $\mathrm{SnCl}_{4}[10]$ & $1: 1$ & 0 & 48 & $\mathbf{3 b}[71]^{[\mathrm{b}]}(10)$ \\
\hline 7 & $\mathrm{SnCl}_{4}[50]$ & $2: 1$ & -78 & 16 & $\mathbf{1}[90], \mathbf{3 b}[10]$ \\
\hline 8 & $\mathrm{SnCl}_{4}[100]$ & $1: 1$ & -78 & 72 & 3b [96] (66) \\
\hline
\end{tabular}

[a] Determined from the GLC peak area, isolated yield in parenthesis. [b] Substantial amounts of a by-product were obtained.

Stoichiometric $\mathrm{SnCl}_{4}$ was also the promoter of choice in the carbonyl-ene reaction of $\mathbf{1}$ with ethyl pyruvate (2c) (Table 3, entry $3)$. It is noteworthy that, under the reaction conditions tested, partial deprotection towards the corresponding diol $\mathbf{4 c}$ was observed. This fact, rather than being a problem, was somewhat advantageous if we consider that compounds $\mathbf{3}$ were later subjected to protodesilylation. We must point out that carbon-carbon double bond isomerisation occurred when scaling the reaction to $>1 \mathrm{mmol}$, giving rise to a ca. 3:1 mixture of $3 \mathbf{c}$ and (E)-ethyl 6-[(tertbutyldimethylsilyl)oxy]-2-hydroxy-2,4-dimethylhex-4-enoate.

Ethyl 3,3,3-trifluoropyruvate (2d) was found to be a rather problematic enophile despite being more activated than ethyl pyruvate (2c). For instance, stoichiometric $\mathrm{SnCl}_{4}$ afforded near equimolecular ratio of $\mathbf{1}$ and the deprotected product $\mathbf{4 d}$ together with multiple by-products (Table 4 , entry 1 ). The $\mathrm{AgSbF}_{6} /$ racBINAP-PdCl ${ }_{2}$ combination was shown to be somewhat effective only for long reaction times at low temperature (Table 4, entries 24). $\mathrm{EtAlCl}_{2}$ gave low conversion into $3 \mathbf{d}$ together with $22 \%$ of the 
double-bond isomerisation product (E)-ethyl 6-[(tertbutyldimethylsilyl)oxy]-2-hydroxy-4-methyl-2-(trifluoromethyl)hex-4-enoate (Table 4, entry 5). The conversion was improved with $\mathrm{Me}_{2} \mathrm{AlCl}$, though minor amounts of both deprotected and isomerised 3d were also obtained (Table 4, entry 6).

Table 3. Carbonyl-ene reaction of $\mathbf{1}$ with ethyl pyruvate (2c).

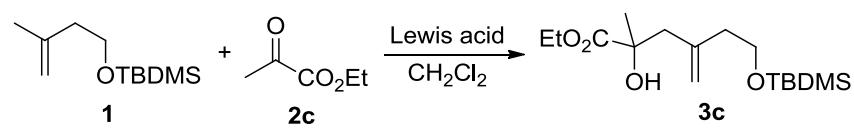

\begin{tabular}{llllll}
\hline Entry & $\begin{array}{l}\text { Lewis acid } \\
{[\mathrm{mol}-\%]}\end{array}$ & $\begin{array}{l}\mathbf{1 / 2 c} \\
{[\mathrm{mmol}]}\end{array}$ & $\begin{array}{l}\mathrm{T} \\
{\left[{ }^{\circ} \mathrm{C}\right]}\end{array}$ & $\begin{array}{l}t \\
{[\mathrm{~h}]}\end{array}$ & $\begin{array}{l}\text { Product } \\
{[\%]^{[\mathrm{a}]}}\end{array}$ \\
\hline 1 & $\mathrm{Me}_{2} \mathrm{AlCl}[220]$ & $1: 1$ & 0 to r.t. & 22 & $\mathbf{1}[93], \mathbf{3 c}[7]$ \\
2 & $\mathrm{EtAlCl}_{2}[220]$ & $1: 1$ & 0 to r.t. & 24 & $\mathbf{3 c}[24], \mathbf{4 c}[10]^{[\mathrm{b}]}$ \\
3 & $\mathrm{SnCl}_{4}[100]$ & $1: 1$ & -78 & 21 & $\mathbf{3 c}[64](40)$, \\
& & & & & $\mathbf{4 c}[15](14)^{[\mathrm{b}]}$ \\
\hline
\end{tabular}

[a] Determined from the GLC peak area, isolated yield in parenthesis. [b] Deprotected 3c.

Table 4. Carbonyl-ene reaction of $\mathbf{1}$ with ethyl 3,3,3-trifluoropyruvate (2d).

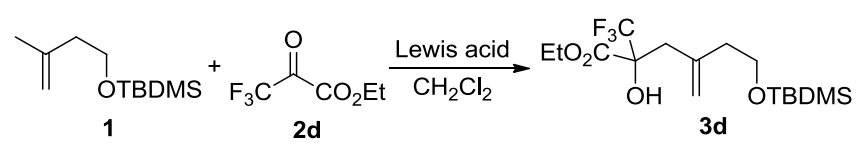

\begin{tabular}{|c|c|c|c|c|c|}
\hline Entry & $\begin{array}{l}\text { Lewis acid } \\
\text { [mol-\%] }\end{array}$ & $\begin{array}{l}\mathbf{1 / 2 d} \\
{[\mathrm{mmol}]}\end{array}$ & $\begin{array}{l}\mathrm{T} \\
{\left[{ }^{\circ} \mathrm{C}\right]}\end{array}$ & $\begin{array}{l}t \\
{[\mathrm{~h}]}\end{array}$ & $\begin{array}{l}\text { Product } \\
{[\%]^{[a]}}\end{array}$ \\
\hline 1 & $\mathrm{SnCl}_{4}[100]$ & $1: 1$ & 0 & 24 & $\mathbf{1}[35], \mathbf{4 d}[40]^{[\mathrm{b}]}$ \\
\hline 2 & $\begin{array}{l}\mathrm{AgSbF}_{6}[11], \\
\text { BINAP-PdCl }_{2}[5]\end{array}$ & $1: 2.2$ & -78 & 4 & $\mathbf{1}[>99]$ \\
\hline 3 & 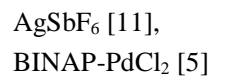 & $1: 2.2$ & -78 & 67 & $\mathbf{1}[65], \mathbf{3 d}[35]$ \\
\hline 4 & 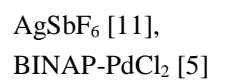 & $1: 1$ & -30 & 44 & $\mathbf{1}[27], \mathbf{3 d}[42]$ \\
\hline 5 & $\mathrm{EtAlCl}_{2}[220]$ & $1: 1$ & 0 to r.t. & 20 & $\mathbf{1}[54], \mathbf{3 d}[23]^{[\mathrm{c}]}$ \\
\hline 6 & $\mathrm{Me}_{2} \mathrm{AlCl}[220]$ & $1: 1$ & 0 to r.t. & 27 & $\begin{array}{l}\mathbf{1}[44], 3 \mathbf{3 d}[50] \\
(12)^{[\mathrm{dd}}, \mathbf{4 d}[6](6)^{[\mathrm{b}}\end{array}$ \\
\hline
\end{tabular}

[a] Determined from the GLC peak area, isolated yield in parenthesis. [b] Deprotected 3d. [c] $22 \%$ of the double bond isomerisation product was obtained. [d] $6 \%$ of the double-bond isomerisation product was obtained.

Diethyl 2-oxomalonate (2e) has been little studied as an enophile in comparison with $(\mathrm{CHO})_{\mathrm{n}}$ or other 2-oxoesters. ${ }^{[19]}$ The resulting $\alpha$-hydroxymalonic esters, once hydrolysed, can undergo oxidative bisdecarboxylation, with the whole sequence being synthetically equivalent to an ene reaction of carbon dioxide. We noted very low conversions with the aluminium Lewis acids as well as with $\mathrm{SnCl}_{4}$ at $0{ }^{\circ} \mathrm{C}$ or room temperature (Table 5, entries 1$5)$. Very modest conversion and isolated yield could be only achieved with $\mathrm{SnCl}_{4}$ at low temperature though, fortunately, the reaction was scalable to $10 \mathrm{mmol}$ (Table 5, entry 6).

We next turned our attention to some enophiles possessing a neat formyl group. The reaction of aliphatic and aromatic aldehydes with alkenes was described to be promoted by $\mathrm{Me}_{2} \mathrm{AlCl}^{[17]}$ We also found out that the reaction of $\mathbf{1}$ with 2,3,4,5,6-pentafluorobenzaldehyde (2f) was better effected with EtAlCl ${ }_{2}$ or $\mathrm{Me}_{2} \mathrm{AlCl}$ than with $\mathrm{SnCl}_{4}$ (Table 6). Among the two former, $\mathrm{Me}_{2} \mathrm{AlCl}$ provided a moderate combined yield of the expected methylidenic alcohol $\mathbf{3 f}$ and the relative deprotected diol 4f (Table 6, entry 3). It is worthy of mention that this reaction could be easily scalable to $5 \mathrm{mmol}$.

Table 5. Carbonyl-ene reaction of $\mathbf{1}$ with diethyl oxomalonate (2e).

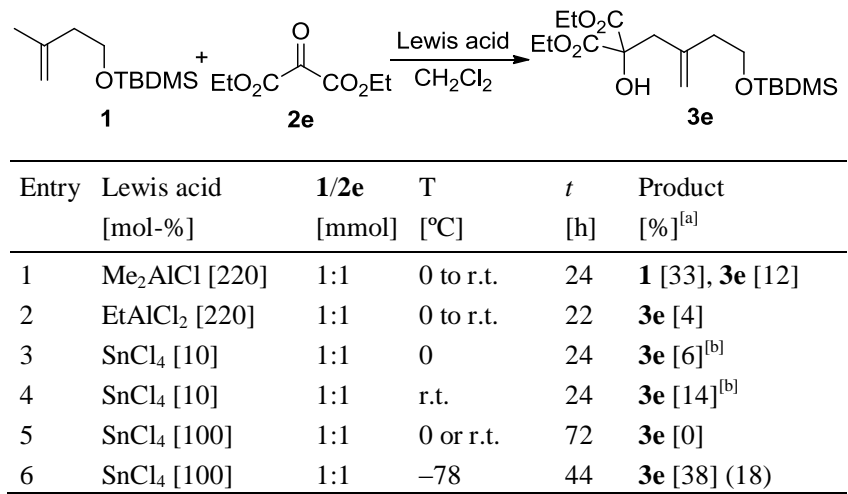

[a] Determined from the GLC peak area, isolated yield in parenthesis. [b] Complex mixture.

Table 6. Carbonyl-ene reaction of $\mathbf{1}$ with 2,3,4,5,6pentafluorobenzaldehyde (2f).

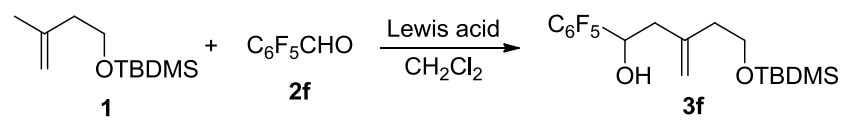

\begin{tabular}{|c|c|c|c|c|c|}
\hline Entry & $\begin{array}{l}\text { Lewis acid } \\
{[\mathrm{mol} \%]}\end{array}$ & $\begin{array}{l}\mathbf{1 / 2 f} \\
{[\mathrm{mmol}]}\end{array}$ & $\begin{array}{l}\mathrm{T} \\
{\left[{ }^{\circ} \mathrm{C}\right]}\end{array}$ & $\begin{array}{l}t \\
{[\mathrm{~h}]}\end{array}$ & $\begin{array}{l}\text { Product } \\
{[\%]^{[a]}}\end{array}$ \\
\hline 1 & $\mathrm{SnCl}_{4}[100]$ & $1: 1$ & 0 & 24 & $\begin{array}{l}\mathbf{1}[46], \mathbf{3 f}[20], \\
\mathbf{4 f}[24]^{[b]}\end{array}$ \\
\hline 2 & $\mathrm{EtAlCl}_{2}[220]$ & $1: 1$ & 0 to r.t. & 1.5 & $\begin{array}{l}\mathbf{1}[8], \mathbf{3 f}[64](38), \\
\mathbf{4 f}[10](8)^{[b]}\end{array}$ \\
\hline 3 & $\mathrm{Me}_{2} \mathrm{AlCl}[220]$ & $1: 1$ & 0 to r.t. & 27 & $\begin{array}{l}\mathbf{1}[11], \mathbf{3 f}[64](55), \\
\mathbf{4 f}[25](10)^{[b]}\end{array}$ \\
\hline
\end{tabular}

[a] Determined from the GLC peak area, isolated yield in parenthesis. [b] Deprotected 3f.

A similar trend to that mentioned above for $\mathbf{2 f}$ was observed when using 6-nitropiperonal (2g) as the enophile, though, in contrast, an intractable reaction crude mixture was obtained with $\mathrm{SnCl}_{4}$ (Table 7, entry 1). In this case, $\mathrm{EtAlCl}_{2}$ displayed slightly better behaviour than $\mathrm{Me}_{2} \mathrm{AlCl}$, with the in-situ deprotection to the corresponding diol reaching the highest conversions recorded for all the enophiles tested in the present research (Table 7, entries 2 and 3).

Table 7. Carbonyl-ene reaction of $\mathbf{1}$ with 6-nitropiperonal (2g).

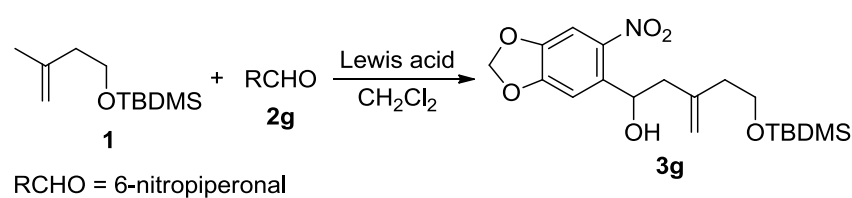

\begin{tabular}{|c|c|c|c|c|c|}
\hline Entry & $\begin{array}{l}\text { Lewis acid } \\
{[\mathrm{mol}-\%]}\end{array}$ & $\begin{array}{l}\mathbf{1} / \mathbf{2 g} \\
{[\mathrm{mmol}]}\end{array}$ & $\begin{array}{l}\mathrm{T} \\
{\left[{ }^{\circ} \mathrm{C}\right]}\end{array}$ & $\begin{array}{l}t \\
{[\mathrm{~h}]}\end{array}$ & $\begin{array}{l}\text { Product } \\
{[\%]^{[a]}}\end{array}$ \\
\hline$\overline{1}$ & $\mathrm{SnCl}_{4}[100]$ & $1: 1$ & -78 & 44 & complex mixture \\
\hline 2 & $\mathrm{Me}_{2} \mathrm{AlCl}[220]$ & $1: 1$ & 0 to r.t. & 24 & $\begin{array}{l}\mathbf{1}[10], \mathbf{3 g}[21], \\
\mathbf{4 g}[69]^{[\mathrm{b}]}\end{array}$ \\
\hline 3 & $\mathrm{EtAlCl}_{2}[220]$ & $1: 1$ & 0 to r.t. & 1 & $\begin{array}{l}\mathbf{3 g}[31](18), \\
\mathbf{4 g}[69](30)^{[\mathrm{b}]}\end{array}$ \\
\hline
\end{tabular}

[a] Determined from the GLC peak area, isolated yield in parenthesis. [b] Deprotected 3g. 


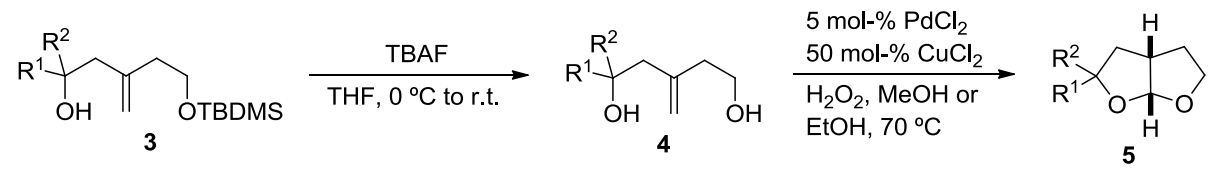

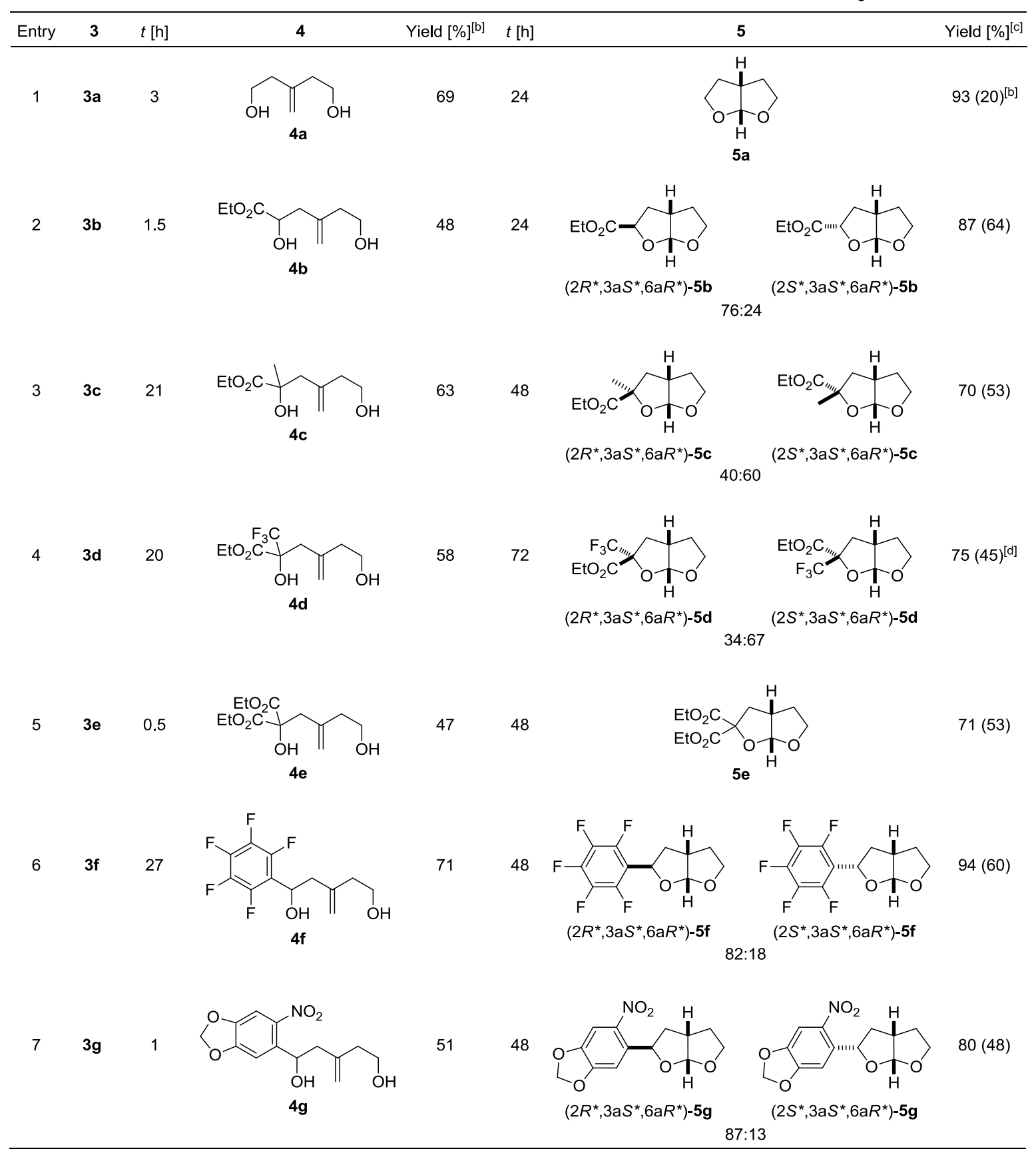

[a] Reaction conditions: 3 ( $1 \mathrm{mmol})$, TBAF $(1.58 \mathrm{mmol})$, THF, $0{ }^{\circ} \mathrm{C}$ to r.t.; 4 ( $\left.1 \mathrm{mmol}\right), \mathrm{PdCl}_{2}(5 \mathrm{~mol}-\%), \mathrm{CuCl}_{2}(50 \mathrm{~mol}-\%), 35 \% \mathrm{H}_{2} \mathrm{O}_{2}$ $(10 \mathrm{mmol}), \mathrm{MeOH}(10 \mathrm{~mL}$, entries 1,6 , and 7) or EtOH (10 mL, entries 2-5). [b] Isolated yield. [c] Conversion into 5 determined by GLC, GLC yield in parenthesis; diastereomeric ratio determined by ${ }^{1} \mathrm{H}$ NMR. [d] Yield determined by ${ }^{1} \mathrm{H}$ NMR.

The next step of the synthetic sequence was to submit all compounds 3 to deprotection. Tetra-( $n$-butyl)ammonium fluoride in THF was used for this purpose under mild conditions and quite distinct reaction times (Table 8). ${ }^{[20]}$ The conversion into the homoallylic alcohols 4 was quantitative with the exception of compound 3e $(60 \%)$. The isolated yields of 4 ranged from modestto good (47-71\%) due to an important loss of mass during the work-up and/or purification (Table 8). With a series of methylidenic diols $\mathbf{4}$ in hand, we studied their palladium-catalysed intramolecular acetalisation, under the Wacker-type conditions previously developed by us. $^{[9,10]}$ The simplest diol, 3methylenepentane-1,5-diol (4a), was transformed into the unsubstituted perhydrofuro[2,3-b]furan 5a in high conversion (Table 8, entry 1 ). The low isolated yield attained was attributed to the high volatility of this compound. This represents the third synthesis of 5a, the previous ones involving the reaction of $\alpha$ litioacetonitrile with protected 2-bromoethanol, deprotection and acetalisation, ${ }^{[5]}$ and the rhodium-catalysed hydroformylation- 
acetalisation of alkenediols. ${ }^{[21]}$ It must be stressed that the reactions with the ethyl oxoester derivatives $4 \mathbf{b}-\mathbf{4 e}$ were carried out in ethanol instead of in methanol in order to prevent transesterification (Table 8, entries 2-5). The perhydrofurofurans $\mathbf{5 b}-\mathbf{5 d}$ were obtained in moderate yields and with some stereoselectivity in favour of the $\left(2 R^{*}, 3 \mathrm{a} S^{*}, 6 \mathrm{a} R^{*}\right)$ diastereoisomer for $\mathbf{5 b}$ and $\left(2 S^{*}, 3 \mathrm{a} S^{*}, 6 \mathrm{a} R^{*}\right)$ diastereoisomer for $\mathbf{5} \mathbf{c}$ and $\mathbf{5 d}$ (Table 8 entries 2-4). The difference in the moderate stereoselectivity observed between these examples follows a similar trend as the difference in the steric contribution of the two substituents at the 2position of the bicycle; i.e., $\mathrm{CO}_{2} \mathrm{Et}$ vs. $\mathrm{H}$ in $\mathbf{5 b}$ gave higher diastereomeric ratio than $\mathrm{CO}_{2} \mathrm{Et}$ vs. $\mathrm{Me}$ or $\mathrm{CF}_{3}$ in $\mathbf{5 c}$ and $\mathbf{5 d}$, respectively. A perhydrofurofuran-2,2-dicarboxylate (5e) was also successfully prepared in moderate yield from the diol derived from diethyl 2-oxomalonate (4e) (Table 8, entry 5). The more steric demanding pentafluorophenyl and 6-nitrobenzo[d][1,3]dioxol-5-yl groups imparted higher diastereoselectivity to the perhydrofurofurans $\mathbf{5 f}$ and $\mathbf{5 g}$, respectively, with the later achieving a maximum ratio of $87: 13$ also in favour of the $\left(2 R^{*}, 3 \mathrm{a} S^{*}, 6 \mathrm{a} R^{*}\right)$ diastereoisomer (Table 8, entries 6 and 7). In general, equal or higher reaction times were needed in order to get high conversions, in comparison with the hydrocarbon-substituted analogues previously synthesised by us. ${ }^{[9,10]}$

The major $\left(2 R^{*}, 3 \mathrm{a} S^{*}, 6 \mathrm{a} R^{*}\right)$ relative configuration observed for $\mathbf{5 b}, \mathbf{5 f}$, and $\mathbf{5 g}$ is in agreement with that reported by us for 2,5disubstituted and 2-monosubstituted perhydrofuro[2,3$b]$ furans, ${ }^{[9,10]}$ and it was confirmed by n.O.e. experiments conducted on both diastereoisomers of compound $\mathbf{5 b}$ (Figure 2). A small n.O.e. was observed for $2-\mathrm{H}$ and $3 \mathrm{a}-\mathrm{H}$ in both diastereoisomers, whereas n.O.e. between $2-\mathrm{H}$ and $5-\mathrm{H}$ was manifested only in the major diastereoisomer. We believe that, by analogy with the perhydrofurofuran bearing a phenyl group at the 2-position, ${ }^{[10]}$ the location of $2-\mathrm{H}$ and $5-\mathrm{H}$ in $\left(2 R^{*}, 3 \mathrm{a} S^{*}, 6 \mathrm{a} R^{*}\right)-\mathbf{5 b}$ is closer compared with that in $\left(2 S^{*}, 3 \mathrm{a} S^{*}, 6 \mathrm{a} R^{*}\right)-\mathbf{5 b}$, what would explain the shown n.O.e. (Figure 2). In the same vein, we discussed about the opposite stereoselectivity exhibited by $\mathbf{5 c}$ and $\mathbf{5 d}$, favouring the $\left(2 S^{*}, 3 \mathrm{a} S^{*}, 6 \mathrm{a} R^{*}\right)$ diastereoisomer. The stereochemistry was also established on the basis of n.O.e experiments performed on compound $\mathbf{5 c}$. As depicted in Figure 3, n.O.e between $2-\mathrm{H}$ and $5-\mathrm{Me}$ in $\left(2 R^{*}, 3 \mathrm{a} S^{*}, 6 \mathrm{a} R^{*}\right)-5 \mathrm{c}$ is in concordance with the short interatomic distance measured on its geometry-optimised model (PM3 semiempirical method was applied). ${ }^{[22]}$ In contrast, this particular n.O.e. was not detected for the major diastereoisomer $\left(2 S^{*}, 3 \mathrm{a} S^{*}, 6 \mathrm{a} R^{*}\right)-\mathbf{5} \mathbf{c}$, where the mentioned nuclei are far away. The stereochemistry of $\mathbf{5 d}$, in which the bulkier trifluoromethyl group is present, could be rationalised likewise.

It is worthwhile mentioning that the relative stereochemistry in compounds 5 could be nicely correlated with the ${ }^{1} \mathrm{H}$ NMR chemical shift of the acetal hydrogen H-6a (Table 9). In all cases, $\mathrm{H}-6 \mathrm{a}$ appeared more deshielded in $\left(2 R^{*}, 3 \mathrm{a} S^{*}, 6 \mathrm{a} R^{*}\right)-5$ than in $\left(2 S^{*}, 3 \mathrm{a} S^{*}, 6 \mathrm{a} R^{*}\right)-5$, with a chemical shift range of 5.87-6.02 and 5.75-5.95 ppm, respectively. Furthermore, the difference in chemical shift was larger (ca. double $\Delta \delta$ ) in the 2-monosubstituted series (Table 9, entries 1, 4, and 5) than in the 2,2-disubstituted derivatives (Table 9, entries 2 and 3). Indeed this seems to be a direct and reliable method to assign the relative stereochemistry of 2-substituted perhydrofuro[2,3- $b$ ]furans (whenever both diastereoisomers are available), as the same tendency was observed for perhydrofuro[2,3-b]furans with a hydrocarbon substituent at the 2-position ${ }^{[10]}$ or 2,5-positions. ${ }^{[7]}$

A reaction mechanism for this palladium-catalysed intramolecular acetalisation was proposed in our original contribution, ${ }^{[9]}$ in terms of oxypalladation-dehydropalladation
Table 9. ${ }^{1} \mathrm{H}$ NMR chemical shifts of $\mathrm{H}-6 \mathrm{a}$ in $\left(2 R^{*}, 3 \mathrm{a} S^{*}, 6 \mathrm{a} R^{*}\right)-5$ and $\left(2 S^{*}, 3 \mathrm{a} S^{*}, 6 \mathrm{a} R^{*}\right)-\mathbf{5}^{\text {[a] }}$

\begin{tabular}{lllll}
\hline Entry & Compound $\mathbf{5}$ & $\begin{array}{l}\left(2 R^{*}, 3 \mathrm{a} S^{*}, 6 \mathrm{a} R^{*}\right) \\
\delta[\mathrm{ppm}]\end{array}$ & $\begin{array}{l}\left(2 S^{*}, 3 \mathrm{a} S^{*}, 6 \mathrm{a} R^{*}\right) \\
\delta[\mathrm{ppm}]\end{array}$ & $\begin{array}{l}\Delta \delta \\
{[\mathrm{ppm}]}\end{array}$ \\
\hline 1 & $\mathbf{5 b}$ & 5.91 & 5.77 & 0.14 \\
2 & $\mathbf{5 c}$ & 5.87 & 5.79 & 0.08 \\
3 & $\mathbf{5 d}$ & 6.02 & 5.95 & 0.07 \\
4 & $\mathbf{5 f}$ & 5.91 & 5.75 & 0.16 \\
5 & $\mathbf{5 g}$ & 5.97 & 5.82 & 0.15 \\
\hline
\end{tabular}

[a] Chemical shifts recorded at $400 \mathrm{MHz}$ using $\mathrm{CDCl}_{3}$ as solvent and TMS as internal standard.
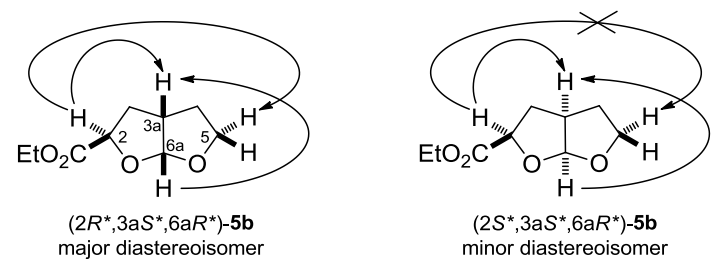

Figure 2. n.O.e. experiments for the diastereoisomers of $\mathbf{5 b}$
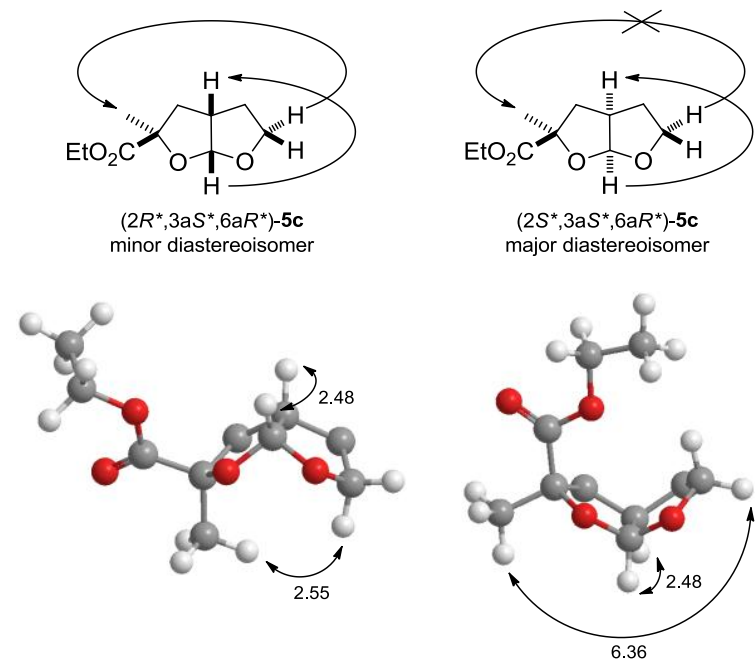

Figure 3. n.O.e. experiments and optimised-geometry models for the diastereoisomers of 5c. Numbers on the arrows refer to interatomic distances in $\AA$. Some hydrogen atoms have been omitted for clarity.

reactions. ${ }^{[23]}$ We tried to rationalise the differences in diastereoselectivity observed between the 2-monosubstituted and 2,5-disubstituted perhydrofurofurans. The diastereomeric ratios of the former, containing hydrocarbon substituents $(85: 15-93: 7),{ }^{[10]}$ were akin to those discussed in this article $(76: 24-87: 13)$ but in both cases lower than those obtained for the 2,5-disusbtituted derivatives $(94: 6->99: 1) .{ }^{[9]}$ In the latter case, two plausible $\pi$ palladium hydride complexes VI and IX were proposed, resulting from a first cyclisation, followed by the corresponding hypothetical transition states VII and $\mathbf{X}$ suggested for the second cyclisation (Scheme 2). Unfavourable steric interactions involving the two $\mathrm{R}$ groups in the transition state VII, which are absent in $\mathbf{X}$, could account for the preferential formation of perhydrofurofuran $\beta$-cis-6 through the intermediate XI. A similar argument was invoked to explain the $\beta$-cis-5 as being the mayor diastereoisomer in the 2substituted perhydrofurofuran series. In this case, however, the energy difference between the hypothetical transition states XIII and XVI must be lower than between VII and $\mathbf{X}$, and thus there is a decrease in the diastereoselectivity. 


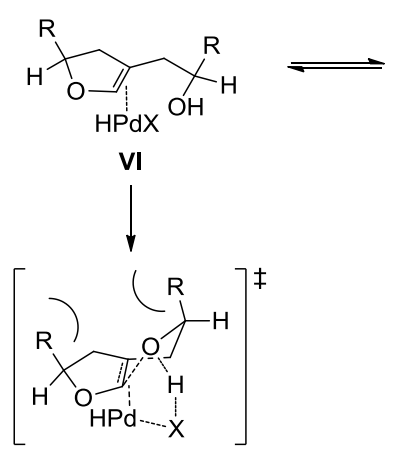

VII

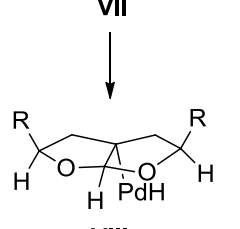

VIII

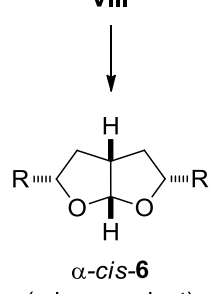

(minor product)
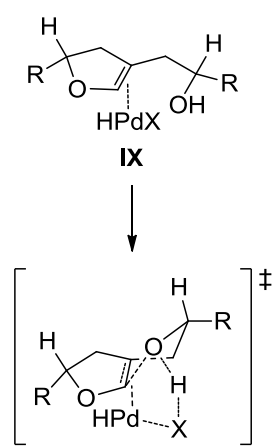

$\mathbf{X}$

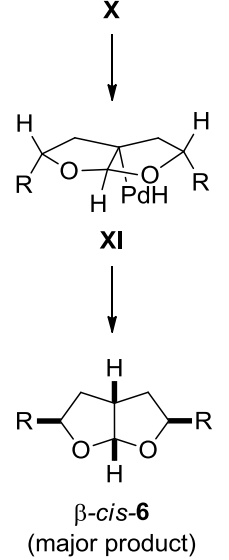

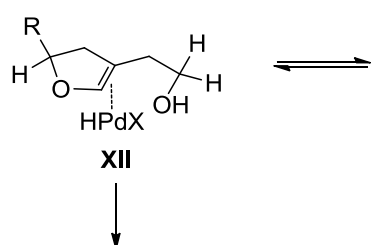

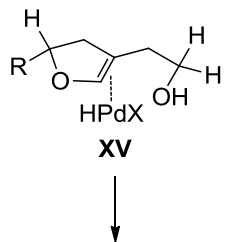

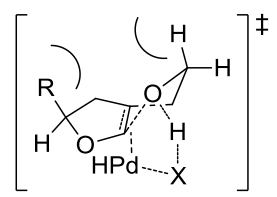

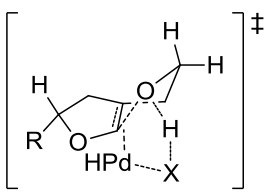

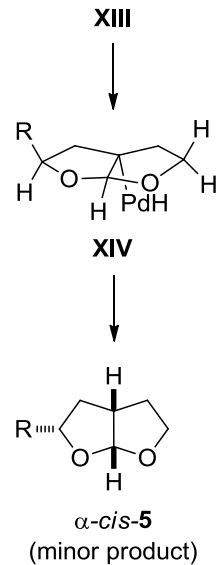

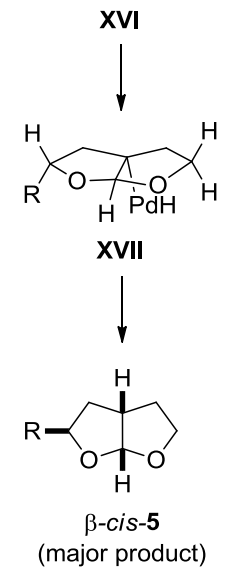

Scheme 2. Intermediates and transition states proposed to explain the diastereoselectivity in the synthesis of 2,5-disubstituted and 2-monosubstituted perhydrofuro[2,3-b]furans.

\section{Conclusions}

We have devised a new route toward the synthesis of perhydrofuro[2,3-b]furans consisting of: (a) protection of isopentenyl alcohol, (b) carbonyl-ene reaction with paraformaldehyde and various activated enophiles, (c) alcohol deprotection, and (d) palladium-catalysed intramolecular acetalisation under Wacker-type reaction conditions. In the ene reaction, tin(IV) chloride was the Lewis acid of choice for ethyl glyoxylate, ethyl pyruvate and ethyl 2-oxomalonate, whereas dimethylaluminium chloride behaved better for paraformaldehyde, ethyl trifluoropyruvate and pentafluorobenzaldehyde, and ethylaluminium dichloride for 6-nitropiperonal. The resulting homoallylic diols were transformed into the corresponding perhydrofurofurans in modest yields and variable diastereoselectivity, which was lower than that found for the 2,5disubstituted analogues. The relative stereochemistry of the perhydrofurofurans was unequivocally established on the basis of n.O.e. experiments.

\section{Experimental Section}

General: Dimethylaluminium chloride and ethylaluminiumdichloride were purchased as a 1.0 M solution in hexane from Aldrich. Tin(IV) chloride, 3methylbut-3-en-1-ol, paraformaldehyde, ethyl pyruvate, ethyl 3,3,3trifluoropyruvate, diethyl ketomalonate, 2,3,4,5,6-pentafluorobenzaldehyde, and 6-nitropiperonal were commercially available of the best grade (Aldrich and Alfa Aesar) and were used without further purification. Ethyl glyoxylate (50\% in toluene, Aldrich) was distilled prior to use. Dry THF and dichloromethane were dried in a Sharlab PS-400-3MD solvent purification system using an alumina column. Tetra- $n$-(butyl)ammonium fluoride was purchased as a 1.0 M solution in THF (Alfa Aesar).
Infrared analysis was performed with FT-IR Nicolet Impact 400D and Jasco 4100LE (Pike MIRacle ATR) spectrophotometers; wavenumbers are given in $\mathrm{cm}^{-1}$. NMR spectra were recorded on Bruker Avance 300 and 400 spectrometers (300 and $400 \mathrm{MHz}$ for ${ }^{1} \mathrm{H}$ NMR; 75 and $100 \mathrm{MHz}$ for ${ }^{13} \mathrm{C}$ NMR) using $\mathrm{CDCl}_{3}$ as solvent and TMS as internal standard; chemical shifts are given in $(\delta)$ parts per million and coupling constants $(J)$ in Hertz; Mass spectra (EI) were obtained at $70 \mathrm{eV}$ on an Agilent 5973 spectrometer; fragment ions in $\mathrm{m} / \mathrm{z}$, with relative intensities (\%) in parenthesis. HRMS analyses were carried out on a Finnigan MAT95S spectrometer. The purity of volatile compounds and the chromatographic analyses (GLC) were determined with a Hewlett Packard HP-6890 instrument equipped with a flame ionisation detector and a $30 \mathrm{~m}$ capillary column $(0.32 \mathrm{~mm}$ diameter, $0.25 \mu \mathrm{m}$ film thickness), using nitrogen $(2 \mathrm{~mL} / \mathrm{min})$ as carrier gas, $T_{\text {injector }}=$ $275{ }^{\circ} \mathrm{C}, T_{\text {column }}=60^{\circ} \mathrm{C}(3 \mathrm{~min})$ and $60-270{ }^{\circ} \mathrm{C}\left(15^{\circ} \mathrm{C} / \mathrm{min}\right)$; retention times $\left(t_{\mathrm{r}}\right)$ are given in min. Flash column chromatography was performed using silica gel 60 of 40-60 microns.

\section{General procedures for the carbonyl-ene reaction:}

Method A: ${ }^{[17]}$ The Lewis acid solution $\left(\mathrm{Me}_{2} \mathrm{AlCl}\right.$ or $\mathrm{EtAlCl}_{2}, 2.2 \mathrm{mmol}$ ) was added, via syringe and under nitrogen, to an ice-bath cooled solution of the enophile $(\mathbf{2}, 1 \mathrm{mmol})$ and protected isopentenyl alcohol $(\mathbf{1}, 0.2 \mathrm{~g}, 1 \mathrm{mmol})$ in dry $\mathrm{CH}_{2} \mathrm{Cl}_{2}(5 \mathrm{~mL})$. The ice bath was removed after the addition and the solution stirred and monitored by GLC and/or TLC. Work-up was performed by the slow addition of $5 \mathrm{~mL}$ of a $\mathrm{NaH}_{2} \mathrm{PO}_{4}$ saturated aqueous solution and $10 \mathrm{~mL}$ of $\mathrm{Et}_{2} \mathrm{O}$ to the reaction mixture. The precipitated alumina was dissolved by the dropwise addition of $10 \% \mathrm{HCl}$. The organic layer was separated by decantation, the aqueous phase was extracted with $\mathrm{Et}_{2} \mathrm{O}(3 \times 10 \mathrm{~mL})$, and the combined organic layers were dried with anhydrous $\mathrm{MgSO}_{4}$ and evaporated in vacuo. The residue obtained was subjected to flash chromatography (silica gel, hexane/EtOAc) to yield the corresponding ene adducts 3 .

Method B: ${ }^{[24]} \mathrm{SnCl}_{4}(0.12 \mathrm{~mL}, 1 \mathrm{mmol})$ was added dropwise to a stirred solution of the appropriate enophile $(2,1 \mathrm{mmol})$ and protected isopentenyl 
alcohol $(1,0.2 \mathrm{~g}, 1 \mathrm{mmol})$ in dry $\mathrm{CH}_{2} \mathrm{Cl}_{2}(5 \mathrm{~mL})$ at $-78{ }^{\circ} \mathrm{C}$. The mixture was stirred at this temperature for the time indicated in Tables 1-7. Then, saturated aqueous $\mathrm{NaHCO}_{3}(3 \mathrm{~mL})$ was added and the mixture was allowed to warm to room temperature before being partitioned between $\mathrm{CH}_{2} \mathrm{Cl}_{2}$ and water. The organic extract was washed with brine and dried with anhydrous $\mathrm{MgSO}_{4}$. Removal of the solvent under reduced pressure followed by flash chromatography (silica gel, hexane/EtOAc) yielded the corresponding ene adducts 3 .

5-(tert-Butyldimethylsilyloxy)-3-methylenepentan-1-ol (3a): Following Method A (Table 1, entry 8), compound 3a (166 mg, 72\%) was obtained as a colourless oil. $R_{\mathrm{f}}=0.28$ (hexane/EtOAc 10:1); $t_{\mathrm{r}}=11.89 \mathrm{~min} .{ }^{1} \mathrm{H}$ NMR (300 MHz, $\left.\mathrm{CDCl}_{3}\right): \delta=4.92\left(\mathrm{~s}, 2 \mathrm{H}, \mathrm{CH}_{2}=\mathrm{C}\right), 3.76(\mathrm{t}, J=6.7 \mathrm{~Hz}, 2 \mathrm{H}$, $\left.\mathrm{CH}_{2} \mathrm{OH}\right), 3.73\left(\mathrm{t}, J=6.2 \mathrm{~Hz}, 2 \mathrm{H}, \mathrm{CH}_{2} \mathrm{OTBDMS}\right), 2.33(\mathrm{t}, J=6.2 \mathrm{~Hz}, 2 \mathrm{H}$, $\left.\mathrm{CH}_{2} \mathrm{CH}_{2} \mathrm{OTBDMS}\right), 2.28\left(\mathrm{t}, \mathrm{J}=6.7 \mathrm{~Hz}, 2 \mathrm{H}, \mathrm{CH}_{2} \mathrm{CH}_{2} \mathrm{OH}\right), 0.90[\mathrm{~s}, 9 \mathrm{H}$, $\left.\left(\mathrm{CH}_{3}\right)_{3} \mathrm{C}\right], 0.07$ [s, $\left.6 \mathrm{H},\left(\mathrm{CH}_{3}\right)_{2} \mathrm{Si}\right] \mathrm{ppm} .{ }^{13} \mathrm{C} \mathrm{NMR}\left(75 \mathrm{MHz}, \mathrm{CDCl}_{3}\right): \delta=$ $143.6\left(\mathrm{C}=\mathrm{CH}_{2}\right), 113.7\left(\mathrm{CH}_{2}=\mathrm{C}\right), 62.4\left(\mathrm{CH}_{2} \mathrm{OH}\right), 60.6\left(\mathrm{CH}_{2} \mathrm{OTBDMS}\right), 39.6$ $\left(\mathrm{CH}_{2} \mathrm{CH}_{2} \mathrm{OH}\right), 38.8\left(\mathrm{CH}_{2} \mathrm{CH}_{2} \mathrm{OTBDMS}\right), 25.9$ [ $\left.\left(\mathrm{CH}_{3}\right)_{3} \mathrm{C}\right], 18.3\left[\mathrm{C}\left(\mathrm{CH}_{3}\right)_{3}\right]$, $5.4\left[\left(\mathrm{CH}_{3}\right)_{2} \mathrm{Si}\right] \mathrm{ppm}$. IR $\left(\mathrm{CCl}_{4}\right): v^{\sim}=3362,1256,1047,870,836 \mathrm{~cm}^{-1} . \mathrm{MS}$ (EI): $m / z(\%)=229(<1 \%)\left[\mathrm{M}^{+}-\mathrm{H}\right], 144$ (13), 143 (100), 105 (13), 101 (36), 89 (11), 75 (46), 73 (19). HRMS (EI): calcd. for $\mathrm{C}_{12} \mathrm{H}_{25} \mathrm{SiO}_{2}\left[\mathrm{M}^{+}-\mathrm{H}\right]$ 229.1624 ; found 229.1624

Ethyl 6-(tert-butyldimethylsilyloxy)-2-hydroxy-4-methylenehexanoate (3b): Following Method B (Table 2, entry 8), compound 3b (200 mg, 66\%) was obtained as a colourless oil. $R_{\mathrm{f}}=0.25\left(\right.$ hexane/EtOAc 10:1); $t_{\mathrm{r}}=14.84$ min. ${ }^{1} \mathrm{H}$ NMR (300 MHz, $\mathrm{CDCl}_{3}$ ): $\delta=4.94$ (s, $2 \mathrm{H}, \mathrm{CH}_{2}=\mathrm{C}$ ), 4.34 (ddd, $J=$ 8.4, 5.2, $3.9 \mathrm{~Hz}, 1 \mathrm{H}, \mathrm{CHOH}), 4.25$ (q, J=7.1 Hz, $\left.2 \mathrm{H}, \mathrm{OCH}_{2} \mathrm{CH}_{3}\right), 3.76$ (t, $\left.J=6.7 \mathrm{~Hz}, 2 \mathrm{H}, \mathrm{CH}_{2} \mathrm{OTBDMS}\right), 2.95(\mathrm{~d}, J=5.2 \mathrm{~Hz}, 1 \mathrm{H}, \mathrm{OH}), 2.61(\mathrm{dd}, J$ $=14.2,3.9 \mathrm{~Hz}, 1 \mathrm{H}, \mathrm{CHHCH}), 2.38(\mathrm{dd}, J=14.2,8.4 \mathrm{~Hz}, 1 \mathrm{H}, \mathrm{CH} H \mathrm{CH})$, $2.32\left(\mathrm{t}, J=6.7 \mathrm{~Hz}, 2 \mathrm{H}, \mathrm{CH}_{2} \mathrm{CH}_{2} \mathrm{O}\right), 1.31\left(\mathrm{t}, J=7.1 \mathrm{~Hz}, 3 \mathrm{H}, \mathrm{CH}_{3} \mathrm{CH}_{2} \mathrm{O}\right)$, $0.90\left[\mathrm{~s}, 9 \mathrm{H},\left(\mathrm{CH}_{3}\right)_{3} \mathrm{C}\right], 0.07$ [s, $\left.6 \mathrm{H},\left(\mathrm{CH}_{3}\right)_{2} \mathrm{Si}\right] \mathrm{ppm} .{ }^{13} \mathrm{C} \mathrm{NMR}(75 \mathrm{MHz}$, $\left.\mathrm{CDCl}_{3}\right): \delta=174.5\left(\mathrm{CO}_{2}\right), 142.4\left(C=\mathrm{CH}_{2}\right), 114.8\left(\mathrm{CH}_{2}=\mathrm{C}\right), 69.5\left(\mathrm{CHCH}_{2}\right)$, $62.4\left(\mathrm{OCH}_{2} \mathrm{CH}_{3}\right), 61.6\left(\mathrm{CH}_{2} \mathrm{OTBDMS}\right), 41.4\left(\mathrm{CH}_{2} \mathrm{CH}\right), 39.0\left(\mathrm{CH}_{2} \mathrm{CH}_{2} \mathrm{O}\right)$, $25.9\left[\left(\mathrm{CH}_{3}\right)_{3} \mathrm{C}\right], 18.3\left[\mathrm{C}\left(\mathrm{CH}_{3}\right)_{3}\right], 14.2\left(\mathrm{CH}_{3} \mathrm{CH}_{2} \mathrm{O}\right),-5.4\left[\left(\mathrm{CH}_{3}\right)_{2} \mathrm{Si}\right] \mathrm{ppm}$. IR $\left(\mathrm{CCl}_{4}\right): v^{\sim}=3415,1738,1259,1099$. MS (EI): $\mathrm{m} / z(\%)=257(4)\left[\mathrm{M}^{+}\right.$ $\left.\mathrm{C}_{2} \mathrm{H}_{5} \mathrm{O}\right], 227$ (15), 215 (100), 171 (69), 143 (41), 141 (39), 131 (26), 103 (20), 101 (19), 97 (20), 89 (23), 75 (86), 73 (42). HRMS (EI): calcd. for $\mathrm{C}_{13} \mathrm{H}_{25} \mathrm{SiO}_{3}\left[\mathrm{M}^{+}-\mathrm{C}_{2} \mathrm{H}_{5} \mathrm{O}\right] 257.1573$; found 257.1589 .

Ethyl 6-(tert-butyldimethylsilyloxy)-2-hydroxy-2-methyl-4methylenehexanoate (3c): Following Method B (Table 3, entry 3), compound 3c (130 mg, 40\%) was obtained, together with $4 \mathbf{c}(28 \mathrm{mg}, 14 \%)$, as a colourless oil. $R_{\mathrm{f}}=0.35$ (hexane/EtOAc 15:1); $t_{\mathrm{r}}=14.83 \mathrm{~min} .{ }^{1} \mathrm{H}$ NMR $\left(400 \mathrm{MHz}, \mathrm{CDCl}_{3}\right): \delta=4.87,4.81\left(2 \mathrm{~s}, 2 \mathrm{H}, \mathrm{CH}_{2}=\mathrm{C}\right), 4.17,4.15$ (2 dq, $J=$ 10.5, 7.1 Hz, $2 \mathrm{H}, \mathrm{OCH}_{2} \mathrm{CH}_{3}$ ), 3.66 (t, $J=6.8 \mathrm{~Hz}, 2 \mathrm{H}, \mathrm{CH}_{2} \mathrm{OTBDMS}$ ), $2.53,2.33\left(2 \mathrm{~d}, J=13.8 \mathrm{~Hz}, 2 \mathrm{H}, \mathrm{CCH}_{2} \mathrm{C}\right), 2.28,2.22(2 \mathrm{dt}, J=14.7,6.8 \mathrm{~Hz}$, $\left.2 \mathrm{H}, \mathrm{CH}_{2} \mathrm{CH}_{2} \mathrm{O}\right), 1.37$ (s, $\left.3 \mathrm{H}, \mathrm{CCH}_{3}\right), 1.25\left(\mathrm{t}, J=7.1 \mathrm{~Hz}, 3 \mathrm{H}, \mathrm{CH}_{3} \mathrm{CH}_{2} \mathrm{O}\right.$ ), $0.84\left[\mathrm{~s}, 9 \mathrm{H},\left(\mathrm{CH}_{3}\right)_{3} \mathrm{C}\right], 0.01\left[\mathrm{~s}, 6 \mathrm{H},\left(\mathrm{CH}_{3}\right)_{2} \mathrm{Si}\right] \mathrm{ppm} .{ }^{13} \mathrm{C} \mathrm{NMR}(75 \mathrm{MHz}$, $\left.\mathrm{CDCl}_{3}\right): \delta=176.6\left(\mathrm{CO}_{2}\right), 142.4\left(C=\mathrm{CH}_{2}\right), 115.7\left(\mathrm{CH}_{2}=\mathrm{C}\right), 74.8(\mathrm{COH})$, $62.3\left(\mathrm{OCH}_{2} \mathrm{CH}_{3}\right), 61.6\left(\mathrm{CH}_{2} \mathrm{OTBDMS}\right), 46.2\left(\mathrm{CCH}_{2} \mathrm{C}\right), 40.0\left(\mathrm{CH}_{2} \mathrm{CH}_{2} \mathrm{O}\right)$, $26.4\left(\mathrm{CH}_{3} \mathrm{C}\right), 25.9\left[\left(\mathrm{CH}_{3}\right)_{3} \mathrm{C}\right], 18.3\left[\mathrm{C}\left(\mathrm{CH}_{3}\right)_{3}\right], 14.2\left(\mathrm{CH}_{3} \mathrm{CH}_{2} \mathrm{O}\right),-5.3$ $\left[\left(\mathrm{CH}_{3}\right)_{2} \mathrm{Si}\right] \mathrm{ppm}$. IR $\left(\mathrm{CCl}_{4}\right): v^{\sim}=3435,1733,1698,1255,1205,1109,837$ $\mathrm{cm}^{-1}$. MS (EI): $\mathrm{m} / \mathrm{z}(\%)=316(<1 \%)\left[\mathrm{M}^{+}\right], 229$ (32), 185 (96), 183 (33), 145 (32), 111 (53), 89 (33), 75 (100), 73 (61). HRMS (EI): calcd. for $\mathrm{C}_{14} \mathrm{H}_{27} \mathrm{SiO}_{3}\left[\mathrm{M}^{+}-\mathrm{C}_{2} \mathrm{H}_{5} \mathrm{O}\right] 271.1729$; found 271.1717.

Ethyl 6-(tert-butyldimethylsilyloxy)-2-hydroxy-4-methylene-2(trifluoromethyl)hexanoate (3d): Following Method A (Table 4, entry 6), compound 3d (44 mg, 12\%) was obtained, together with 4d (15 mg, 6\%), as a colourless oil. $R_{\mathrm{f}}=0.28$ (hexane/EtOAc 10:1); $t_{\mathrm{r}}=14.09 \mathrm{~min} .{ }^{1} \mathrm{H}$ NMR $\left(300 \mathrm{MHz}, \mathrm{CDCl}_{3}\right): \delta=4.97,4.94\left(2 \mathrm{~s}, 2 \mathrm{H}, \mathrm{CH}_{2}=\mathrm{C}\right), 4.36,4.32(2 \mathrm{dq}, J=$ 10.6, $\left.7.1 \mathrm{~Hz}, 2 \mathrm{H}, \mathrm{OCH}_{2} \mathrm{CH}_{3}\right), 3.74(\mathrm{td}, J=6.4,2.0 \mathrm{~Hz}, 2 \mathrm{H}$,
$\mathrm{CH}_{2} \mathrm{OTBDMS}$ ), 2.80, $2.69\left(2 \mathrm{~d}, J=14.1 \mathrm{~Hz}, 2 \mathrm{H}, \mathrm{CCH}_{2} \mathrm{C}\right), 2.42,2.29$ (2 dt, $\left.J=14.6,6.4 \mathrm{~Hz}, 2 \mathrm{H}, \mathrm{CH}_{2} \mathrm{CH}_{2} \mathrm{O}\right), 1.35\left(\mathrm{t}, J=7.1 \mathrm{~Hz}, 3 \mathrm{H}, \mathrm{CH}_{3} \mathrm{CH}_{2} \mathrm{O}\right), 0.91$ [s, $\left.9 \mathrm{H},\left(\mathrm{CH}_{3}\right)_{3} \mathrm{C}\right], 0.08\left[\mathrm{~s}, 6 \mathrm{H},\left(\mathrm{CH}_{3}\right)_{2} \mathrm{Si}\right] \mathrm{ppm} .{ }^{13} \mathrm{C} \mathrm{NMR}(100 \mathrm{MHz}$, $\left.\mathrm{CDCl}_{3}\right): \delta=169.2\left(\mathrm{CO}_{2}\right), 140.3\left(C=\mathrm{CH}_{2}\right), 123.3\left(\mathrm{q},{ }^{1} J_{\mathrm{C}-\mathrm{F}}=287.0 \mathrm{~Hz}, \mathrm{CF}_{3}\right)$, $116.9\left(\mathrm{CH}_{2}=\mathrm{C}\right), 78.4\left(\mathrm{q},{ }^{2} J_{\mathrm{C}-\mathrm{F}}=28.6 \mathrm{~Hz}, \mathrm{CCF}_{3}\right), 63.4\left(\mathrm{OCH}_{2} \mathrm{CH}_{3}\right), 62.4$ $\left(\mathrm{CH}_{2} \mathrm{OTBDMS}\right), 39.9\left(\mathrm{CCH}_{2} \mathrm{C}\right), 37.4\left(\mathrm{CH}_{2} \mathrm{CH}_{2} \mathrm{O}\right), 25.9\left[\left(\mathrm{CH}_{3}\right)_{3} \mathrm{C}\right], 18.3$ $\left[C\left(\mathrm{CH}_{3}\right)_{3}\right], 14.0\left(\mathrm{CH}_{3} \mathrm{CH}_{2} \mathrm{O}\right),-5.4\left[\left(\mathrm{CH}_{3}\right)_{2} \mathrm{Si}\right] \mathrm{ppm}$. IR $\left(\mathrm{CCl}_{4}\right): \sim \widetilde{v}=3494$, $1742,1310,1251,1128,1099,836,776,697 \mathrm{~cm}^{-1}$. MS (EI): $\mathrm{m} / z(\%)=325$ (4) $\left[\mathrm{M}^{+}-\mathrm{C}_{2} \mathrm{H}_{5} \mathrm{O}\right], 295$ (22), 283 (100), 255 (25), 107 (25), 99 (26), 97 (21), 95 (23), 89 (52), 80 (25), 77 (81), 75 (54), 73 (85), 67 (24). HRMS (EI): calcd. for $\mathrm{C}_{14} \mathrm{H}_{24} \mathrm{SiO}_{3} \mathrm{~F}_{3}\left[\mathrm{M}^{+}-\mathrm{C}_{2} \mathrm{H}_{5} \mathrm{O}\right] 325.1447$; found 325.1452 .

\section{Diethyl 2-[4-(tert-butyldimethylsilyloxy)-2-methylenebutyl]-2-} hydroxymalonate (3e): Following Method B (Table 5, entry 6), compound 3e $(67 \mathrm{mg}, 18 \%)$ was obtained as a colourless oil. $R_{\mathrm{f}}=0.27$ (hexane/EtOAc $15: 1) ; t_{\mathrm{r}}=15.45 \mathrm{~min} .{ }^{1} \mathrm{H} \mathrm{NMR}\left(400 \mathrm{MHz}, \mathrm{CDCl}_{3}\right): \delta=4.90(\mathrm{~s}, 2 \mathrm{H}$, $\left.\mathrm{CH}_{2}=\mathrm{C}\right), 4.24\left(\mathrm{q}, J=7.1 \mathrm{~Hz}, 4 \mathrm{H}, 2 \times \mathrm{CH}_{2} \mathrm{CH}_{3}\right), 3.70(\mathrm{t}, J=6.7 \mathrm{~Hz}, 2 \mathrm{H}$, $\mathrm{CH}_{2} \mathrm{OTBDMS}$ ), $2.82\left(\mathrm{~s}, 2 \mathrm{H}, \mathrm{CCH}_{2} \mathrm{C}\right.$ ), $2.32\left(\mathrm{t}, \mathrm{J}=6.7 \mathrm{~Hz}, 2 \mathrm{H}, \mathrm{CH}_{2} \mathrm{CH}_{2} \mathrm{O}\right.$ ), $1.28\left(\mathrm{t}, J=7.1 \mathrm{~Hz}, 6 \mathrm{H}, 2 \times \mathrm{CH}_{3} \mathrm{CH}_{2}\right), 0.88\left[\mathrm{~s}, 9 \mathrm{H},\left(\mathrm{CH}_{3}\right)_{3} \mathrm{C}\right], 0.04[\mathrm{~s}, 6 \mathrm{H}$, $\left.\left(\mathrm{CH}_{3}\right)_{2} \mathrm{Si}\right]$ ppm. ${ }^{13} \mathrm{C}$ NMR $\left(75 \mathrm{MHz}, \mathrm{CDCl}_{3}\right): \delta=170.1\left(2 \times \mathrm{CO}_{2}\right), 141.2$ $\left(C=\mathrm{CH}_{2}\right), \quad 115.9 \quad\left(\mathrm{CH}_{2}=\mathrm{C}\right), \quad 79.3(\mathrm{COH}), 62.3\left(2 \times \mathrm{CH}_{2} \mathrm{CH}_{3}\right), 62.1$ $\left(\mathrm{CH}_{2} \mathrm{OTBDMS}\right), 40.2\left(\mathrm{CCH}_{2} \mathrm{C}\right), 40.1\left(\mathrm{CH}_{2} \mathrm{CH}_{2} \mathrm{O}\right), 25.8\left[\left(\mathrm{CH}_{3}\right)_{3} \mathrm{C}\right], 18.2$ $\left[\mathrm{C}\left(\mathrm{CH}_{3}\right)_{3}\right], 14.0\left(2 \times \mathrm{CH}_{3} \mathrm{CH}_{2}\right),-5.4\left[\left(\mathrm{CH}_{3}\right)_{2} \mathrm{Si}\right] \mathrm{ppm}$. IR $\left(\mathrm{CCl}_{4}\right): v^{\sim}=3495$, $2857,1740,1255,1214,1081,837 \mathrm{~cm}^{-1}$. MS (EI): $m / z(\%)=374(<1 \%)$ [M $\mathrm{M}^{+}$, 287 (56), 243 (33), 215 (54), 189 (87), 95 (42), 89 (32), 75 (100). HRMS (EI): calcd. for $\mathrm{C}_{16} \mathrm{H}_{29} \mathrm{SiO}_{5}\left[\mathrm{M}^{+}-\mathrm{C}_{2} \mathrm{H}_{5} \mathrm{O}\right] 329.1784$; found 329.1783 .

5-(tert-Butyldimethylsilyloxy)-3-methylene-1-

(pentafluorophenyl)pentan-1-ol (3f): Following Method A (Table 6, entry 3), compound 3f (218 mg, 55\%) was obtained, together with $\mathbf{4 f}$ ( $28 \mathrm{mg}$, $10 \%$ ), as a colourless oil. $R_{\mathrm{f}}=0.35$ (hexane/EtOAc 10:1); $t_{\mathrm{r}}=15.85 \mathrm{~min} .{ }^{1} \mathrm{H}$ NMR (300 MHz, $\left.\mathrm{CDCl}_{3}\right): \delta=5.25(\mathrm{dd}, J=9.5,4.9 \mathrm{~Hz}, 1 \mathrm{H}, \mathrm{CHOH}), 4.99$, 4.98 ( $2 \mathrm{~s}, 2 \mathrm{H}, \mathrm{CH}_{2}=\mathrm{C}$ ), 3.82 (t, $J=6.2 \mathrm{~Hz}, 2 \mathrm{H}, \mathrm{CH}_{2} \mathrm{OTBDMS}$ ), 3.15 (br s, $1 \mathrm{H}, \mathrm{OH}), 2.82(\mathrm{dd}, J=13.8,9.5 \mathrm{~Hz}, 1 \mathrm{H}, \mathrm{CHHCH}), 2.53(\mathrm{dd}, J=13.8,4.9$ $\mathrm{Hz}, 1 \mathrm{H}, \mathrm{CH} H \mathrm{CH}), 2.34\left(\mathrm{t}, J=6.2 \mathrm{~Hz}, 2 \mathrm{H}, \mathrm{CH}_{2} \mathrm{CH}_{2} \mathrm{O}\right), 0.91[\mathrm{~s}, 9 \mathrm{H}$, $\left.\left(\mathrm{CH}_{3}\right)_{3} \mathrm{C}\right], 0.09$ [s, $\left.6 \mathrm{H},\left(\mathrm{CH}_{3}\right)_{2} \mathrm{Si}\right] \mathrm{ppm} .{ }^{13} \mathrm{C} \mathrm{NMR}\left(100 \mathrm{MHz}, \mathrm{CDCl}_{3}\right): \delta=$ $144.8\left(\mathrm{~d},{ }^{1} J_{\mathrm{C}-\mathrm{F}}=251.0 \mathrm{~Hz}, \mathrm{ArCF}\right), 142.7\left(C=\mathrm{CH}_{2}\right), 140.5\left(\mathrm{~d},{ }^{1} J_{\mathrm{C}-\mathrm{F}}=253.5\right.$ $\mathrm{Hz}, \mathrm{ArCF}), 137.5$ (d, $\left.{ }^{1} J_{\mathrm{C}-\mathrm{F}}=253.5 \mathrm{~Hz}, \mathrm{ArCF}\right), 116.7$ (ArC), $115.7\left(\mathrm{CH}_{2}=\mathrm{C}\right)$, $64.8\left(\mathrm{CHCH}_{2}\right), 62.5\left(\mathrm{CH}_{2} \mathrm{OTBDMS}\right), 43.8\left(\mathrm{CH}_{2} \mathrm{CH}\right), 38.6\left(\mathrm{CH}_{2} \mathrm{CH}_{2} \mathrm{O}\right)$, $25.9\left[\left(\mathrm{CH}_{3}\right)_{3} \mathrm{C}\right], 18.3\left[\mathrm{C}\left(\mathrm{CH}_{3}\right)_{3}\right],-5.4\left[\left(\mathrm{CH}_{3}\right)_{2} \mathrm{Si}\right] \mathrm{ppm}$. IR $\left(\mathrm{CCl}_{4}\right): v^{\sim}=3405$, $1652,1304,1257,1121,837,778 \mathrm{~cm}^{-1}$. MS (EI): $\mathrm{m} / z(\%)=396(<1 \%)$ [M $], 339$ (11), 337 (11), 321 (31), 247 (13), 219 (21), 197 (43), 181 (43), 167 (7), 143 (17), 127 (13), 105 (100), 101 (19), 75 (84). HRMS (EI): calcd. for $\mathrm{C}_{14} \mathrm{H}_{16} \mathrm{SiO}_{2} \mathrm{~F}_{5}\left[\mathrm{M}^{+}-\mathrm{C}_{4} \mathrm{H}_{9}\right]$ 339.0840; found 339.0843.

\section{5-(tert-Butyldimethylsilyloxy)-3-methylene-1-(6-}

nitrobenzo[d][1,3]dioxol-5-yl)pentan-1-ol (3g): Following Method A (Table 7, entry 3), compound $\mathbf{3 g}$ (71 mg, 18\%) was obtained, together with $4 \mathrm{~g}\left(84 \mathrm{mg}, 30 \%\right.$ ), as a orange oil. $R_{\mathrm{f}}=0.27$ (hexane/EtOAc 5:1). ${ }^{1} \mathrm{H}$ NMR $\left(300 \mathrm{MHz} \mathrm{CDCl}_{3}\right): 7.50,7.34(2 \mathrm{~s}, 2 \mathrm{H}, 2 \times \mathrm{ArH}), 6.11\left(\mathrm{~s}, 2 \mathrm{H}, \mathrm{OCH}_{2} \mathrm{O}\right)$, $5.43(\mathrm{dd}, J=9.8,2.4 \mathrm{~Hz}, 1 \mathrm{H}, \mathrm{CHOH}), 5.09,5.06\left(2 \mathrm{~s}, 2 \mathrm{H}, \mathrm{CH}_{2}=\mathrm{C}\right), 3.86$ (td, $\left.J=6.3,2.8 \mathrm{~Hz}, 2 \mathrm{H}, \mathrm{CH}_{2} \mathrm{OTBDMS}\right), 2.72(\mathrm{~d}, J=13.7 \mathrm{~Hz}, 1 \mathrm{H}$, $\mathrm{CHHCH}), 2.41\left(\mathrm{t}, J=6.3 \mathrm{~Hz}, 2 \mathrm{H}, \mathrm{CH}_{2} \mathrm{CH}_{2} \mathrm{O}\right), 2.19(\mathrm{dd}, J=13.7,9.8 \mathrm{~Hz}, 1$ $\mathrm{H}, \mathrm{CH} H \mathrm{CH}), 0.90\left[\mathrm{~s}, 9 \mathrm{H},\left(\mathrm{CH}_{3}\right)_{3} \mathrm{C}\right], 0.08\left[\mathrm{~s}, 6 \mathrm{H},\left(\mathrm{CH}_{3}\right)_{2} \mathrm{Si}\right] \mathrm{ppm} .{ }^{13} \mathrm{C} \mathrm{NMR}$ $\left(75 \mathrm{MHz}, \mathrm{CDCl}_{3}\right): \delta=152.4,146.7,143.5,137.9(4 \times \mathrm{ArC}), 141.1$ $\left(C=\mathrm{CH}_{2}\right), 115.9\left(\mathrm{CH}_{2}=\mathrm{C}\right), 106.9,105.1(2 \times \mathrm{ArCH}), 102.8\left(\mathrm{OCH}_{2} \mathrm{O}\right), 67.6$ $(\mathrm{CHOH}), 62.2\left(\mathrm{CH}_{2} \mathrm{OTBDMS}\right), 46.3\left(\mathrm{CH}_{2} \mathrm{CH}\right), 38.3\left(\mathrm{CH}_{2} \mathrm{CH}_{2} \mathrm{O}\right), 25.9$ $\left[\left(\mathrm{CH}_{3}\right)_{3} \mathrm{C}\right], 18.4\left[\mathrm{C}\left(\mathrm{CH}_{3}\right)_{3}\right],-5.3\left[\left(\mathrm{CH}_{3}\right)_{2} \mathrm{Si}\right] \mathrm{ppm}$. IR $\left(\mathrm{CCl}_{4}\right): v^{\sim}=3411,1618$, $1483,1332,1256,1097,1038,933,836 \mathrm{~cm}^{-1}$. MS (EI-DIP): $m / z(\%)=395$ $(<1 \%)\left[\mathrm{M}^{+}\right], 278$ (16), 220 (23), 196 (32), 143 (50), 131 (31), 75 (60), 69 (100). HRMS (EI-DIP): calcd. for $\mathrm{C}_{19} \mathrm{H}_{29} \mathrm{NSiO}_{6}\left[\mathrm{M}^{+}\right]$395.1764; found 395.1795 . 
General procedure for the deprotection of homoallylic alcohols $3:^{[20]}$ TBAF (1.58 mmol) was added to a stirred solution of the diol $\mathbf{3}(1 \mathrm{mmol})$ in dry THF $(33 \mathrm{~mL})$ previouly cooled in an ice bath. The ice bath was removed and the solution was stirred with monitoring by GLC or TLC. Silica gel was added to the resulting mixture followed by solvent evaporation and flash chromatography (silica gel, hexane/EtOAc).

3-Methylidenepentane-1,5-diol (4a): ${ }^{[17]}$ Colourless liquid. $R_{\mathrm{f}}=0.23$ (hexane/EtOAc 1:4); $t_{\mathrm{r}}=7.86 \mathrm{~min} .{ }^{1} \mathrm{H} \mathrm{NMR}\left(300 \mathrm{MHz}, \mathrm{CDCl}_{3}\right): \delta=5.00(\mathrm{~s}$, $\left.2 \mathrm{H}, \mathrm{CH}_{2}=\mathrm{C}\right), 3.78$ (t, $\left.J=6.2 \mathrm{~Hz}, 4 \mathrm{H}, 2 \times \mathrm{CH}_{2} \mathrm{OH}\right), 2.35$ (t, $J=6.2 \mathrm{~Hz}, 4 \mathrm{H}$, $\left.2 \times \mathrm{CH}_{2} \mathrm{CH}_{2} \mathrm{OH}\right), 1.64($ br s, $2 \mathrm{H}, 2 \times \mathrm{OH}) \mathrm{ppm} .{ }^{13} \mathrm{C} \mathrm{NMR}(75 \mathrm{MHz}$, $\left.\mathrm{CDCl}_{3}\right): \delta=143.3\left(C=\mathrm{CH}_{2}\right), 113.3\left(\mathrm{CH}_{2}=\mathrm{C}\right), 60.4\left(2 \times \mathrm{CH}_{2} \mathrm{OH}\right), 38.8(2 \times$ $\left.\mathrm{CH}_{2} \mathrm{CH}_{2} \mathrm{OH}\right)$ ppm. IR $\left(\mathrm{CCl}_{4}\right): v^{\sim}=3362,3077,1645,1046,897 \mathrm{~cm}^{-1}$. MS (EI): $m / z(\%)=116(<1 \%)\left[\mathrm{M}^{+}\right], 98(5), 86(32), 69(28), 68$ (87), $67(100)$, 56 (44), 53 (36). HRMS (EI): calcd. for $\mathrm{C}_{6} \mathrm{H}_{10} \mathrm{O}\left[\mathrm{M}^{+}-\mathrm{H}_{2} \mathrm{O}\right]$ 98.0732; found 98.0731 .

Ethyl 2,6-dihydroxy-4-methylidenehexanoate (4b): Colourless oil. $R_{\mathrm{f}}=$ 0.38 (hexane/EtOAc 1:4); $t_{\mathrm{r}}=11.11 \mathrm{~min} .{ }^{1} \mathrm{H} \mathrm{NMR}\left(300 \mathrm{MHz}, \mathrm{CDCl}_{3}\right): \delta=$ $5.01\left(\mathrm{~s}, 2 \mathrm{H}, \mathrm{CH}_{2}=\mathrm{C}\right), 4.35(\mathrm{dd}, J=8.4,4.1 \mathrm{~Hz}, 1 \mathrm{H}, \mathrm{CHOH}), 4.25$ (q, $J=$ $\left.7.1 \mathrm{~Hz}, 2 \mathrm{H}, \mathrm{OCH}_{2} \mathrm{CH}_{3}\right), 3.76\left(\mathrm{t}, J=6.2 \mathrm{~Hz}, 2 \mathrm{H}, \mathrm{CH}_{2} \mathrm{OH}\right), 2.60(\mathrm{dd}, J=$ $14.5,4.1 \mathrm{~Hz}, 1 \mathrm{H}, \mathrm{CHHCH}), 2.38(\mathrm{dd}, J=14.5,8.4 \mathrm{~Hz}, 1 \mathrm{H}, \mathrm{CH} H \mathrm{CH})$, $2.37\left(\mathrm{t}, J=6.2 \mathrm{~Hz}, 2 \mathrm{H}, \mathrm{CH}_{2} \mathrm{CH}_{2} \mathrm{O}\right), 1.31\left(\mathrm{t}, J=7.1 \mathrm{~Hz}, 3 \mathrm{H}, \mathrm{CH}_{3} \mathrm{CH}_{2} \mathrm{O}\right)$ ppm. ${ }^{13} \mathrm{C}$ NMR (75 MHz, $\left.\mathrm{CDCl}_{3}\right): \delta=174.5\left(\mathrm{CO}_{2}\right), 141.7\left(\mathrm{C}=\mathrm{CH}_{2}\right), 115.5$ $\left(\mathrm{CH}_{2}=\mathrm{C}\right), 69.7\left(\mathrm{CHCH}_{2}\right), 61.8\left(\mathrm{OCH}_{2} \mathrm{CH}_{3}\right), 60.6\left(\mathrm{CH}_{2} \mathrm{OH}\right), 40.5\left(\mathrm{CH}_{2} \mathrm{CH}\right)$, $39.1\left(\mathrm{CH}_{2} \mathrm{CH}_{2} \mathrm{O}\right), 14.1\left(\mathrm{CH}_{3} \mathrm{CH}_{2} \mathrm{O}\right) \mathrm{ppm}$. IR (ATR): $v^{\sim}=3403,1735,1647$, 1269, 1100, $1041 \mathrm{~cm}^{-1}$. MS (EI): $\mathrm{m} / z(\%)=188(<1 \%)\left[\mathrm{M}^{+}\right], 170(3), 158$ (20), 140 (53), 113 (22), 112 (40), 111 (24), 97 (61), 96 (34), 95 (24), 85 (25), 79 (21), 75 (24), 69 (100), 57 (27), 56 (33), 55 (38), 53 (27). HRMS (EI): calcd. for $\mathrm{C}_{9} \mathrm{H}_{15} \mathrm{O}_{3}\left[\mathrm{M}^{+}-\mathrm{OH}\right]$ 171.1021; found 171.1002 .

Ethyl 2,6-dihydroxy-2-methyl-4-methylidenehexanoate (4c): Colourless oil. $R_{\mathrm{f}}=0.40$ (hexane/EtOAc 1:2); $t_{\mathrm{r}}=11.03 \mathrm{~min} .{ }^{1} \mathrm{H}$ NMR $(300 \mathrm{MHz}$, $\left.\mathrm{CDCl}_{3}\right): \delta=4.97,4.91\left(2 \mathrm{~s}, 2 \mathrm{H}, \mathrm{CH}_{2}=\mathrm{C}\right), 4.17,4.15(2 \mathrm{dq}, J=10.5,7.1 \mathrm{~Hz}$, $\left.2 \mathrm{H}, \mathrm{OCH}_{2} \mathrm{CH}_{3}\right), 3.71\left(\mathrm{t}, J=6.1 \mathrm{~Hz}, 2 \mathrm{H}, \mathrm{CH}_{2} \mathrm{OH}\right), 3.54(\mathrm{~s}, 1 \mathrm{H}, \mathrm{OH}), 2.57$, $2.41\left(2 \mathrm{~d}, J=14.0 \mathrm{~Hz}, 2 \mathrm{H}, \mathrm{CCH}_{2} \mathrm{C}\right), 2.39,2.32(2 \mathrm{dt}, J=14.4,6.1 \mathrm{~Hz}, 2 \mathrm{H}$, $\mathrm{CH}_{2} \mathrm{CH}_{2} \mathrm{O}$ ), 2.08 (br s, $\left.1 \mathrm{H}, \mathrm{OH}\right), 1.42\left(\mathrm{~s}, 3 \mathrm{H}, \mathrm{CCH}_{3}\right), 1.30$ (t, $J=7.1 \mathrm{~Hz}, 3$ $\left.\mathrm{H}, \mathrm{CH}_{3} \mathrm{CH}_{2} \mathrm{O}\right)$ ppm. ${ }^{13} \mathrm{C}$ NMR $\left(75 \mathrm{MHz}, \mathrm{CDCl}_{3}\right): \delta=176.6\left(\mathrm{CO}_{2}\right), 142.0$ $\left(C=\mathrm{CH}_{2}\right), 116.2\left(\mathrm{CH}_{2}=\mathrm{C}\right), 75.0(\mathrm{COH}), 61.8\left(\mathrm{OCH}_{2} \mathrm{CH}_{3}\right), 60.7\left(\mathrm{CH}_{2} \mathrm{OH}\right)$, $45.3\left(\mathrm{CCH}_{2} \mathrm{C}\right), 39.9\left(\mathrm{CH}_{2} \mathrm{CH}_{2} \mathrm{O}\right), 26.6\left(\mathrm{CCH}_{3}\right), 14.1\left(\mathrm{CH}_{3} \mathrm{CH}_{2} \mathrm{O}\right) \mathrm{ppm}$. IR $\left(\mathrm{CCl}_{4}\right): v^{\sim}=3384,1731,1644,1206,1021 \mathrm{~cm}^{-1}$. MS (EI): $\mathrm{m} / z(\%)=202$ $(<1 \%)\left[\mathrm{M}^{+}\right], 117$ (100), 111 (75), 69 (38), 68 (33), 67 (48). HRMS (EI): calcd. for $\mathrm{C}_{10} \mathrm{H}_{18} \mathrm{O}_{4}\left[\mathrm{M}^{+}\right]$202.1205; found 202.1189 .

Ethyl 2,6-dihydroxy-4-methylidene-2-(trifluoromethyl) hexanoate (4d): Colourless oil. $R_{\mathrm{f}}=0.40$ (hexane/EtOAc 1:1); $t_{\mathrm{r}}=11.19 \mathrm{~min} .{ }^{1} \mathrm{H}$ NMR $(300$ $\left.\mathrm{MHz}, \mathrm{CDCl}_{3}\right): \delta=4.99,4.97\left(2 \mathrm{~s}, 2 \mathrm{H}, \mathrm{CH}_{2}=\mathrm{C}\right), 4.52(\mathrm{~s}, 1 \mathrm{H}, \mathrm{OH}), 4.35$, $4.28\left(2 \mathrm{dq}, J=10.7,7.1 \mathrm{~Hz}, 2 \mathrm{H}, \mathrm{OCH}_{2} \mathrm{CH}_{3}\right), 3.72(\mathrm{t}, J=6.3 \mathrm{~Hz}, 2 \mathrm{H}$, $\left.\mathrm{CH}_{2} \mathrm{OH}\right), 2.77,2.64\left(2 \mathrm{~d}, J=14.2 \mathrm{~Hz}, 2 \mathrm{H}, \mathrm{CCH}_{2} \mathrm{C}\right), 2.41,2.32(2 \mathrm{dt}, J=$ $15.2,6.3 \mathrm{~Hz}, 2 \mathrm{H}, \mathrm{CH}_{2} \mathrm{CH}_{2} \mathrm{O}$ ), 1.32 (t, $\left.J=7.1 \mathrm{~Hz}, 3 \mathrm{H}, \mathrm{CH}_{3} \mathrm{CH}_{2} \mathrm{O}\right) \mathrm{ppm} .{ }^{13} \mathrm{C}$ NMR (75 MHz, $\left.\mathrm{CDCl}_{3}\right): \delta=169.2\left(\mathrm{CO}_{2}\right), 139.6\left(C=\mathrm{CH}_{2}\right), 123.2\left(\mathrm{q},{ }^{1} J_{\mathrm{C}-\mathrm{F}}=\right.$ $\left.287.0 \mathrm{~Hz}, \mathrm{CF}_{3}\right), 117.4\left(\mathrm{CH}_{2}=\mathrm{C}\right), 78.4\left(\mathrm{q},{ }^{2} J_{\mathrm{C}-\mathrm{F}}=28.6 \mathrm{~Hz}, \mathrm{CCF}_{3}\right), 63.7$ $\left(\mathrm{OCH}_{2} \mathrm{CH}_{3}\right), 60.6\left(\mathrm{CH}_{2} \mathrm{OH}\right), 39.8\left(\mathrm{CCH}_{2} \mathrm{C}\right), 36.8\left(\mathrm{CH}_{2} \mathrm{CH}_{2} \mathrm{O}\right), 13.9$ $\left(\mathrm{CH}_{3} \mathrm{CH}_{2} \mathrm{O}\right) \mathrm{ppm}$. IR $\left(\mathrm{CCl}_{4}\right): \tilde{v^{2}}=3479,1744,1311,1224,1132,699 \mathrm{~cm}^{-1}$. MS (EI): $m / z(\%)=238(5)\left[\mathrm{M}^{+}-\mathrm{H}_{2} \mathrm{O}\right], 208$ (55), 180 (100), 165 (48), 117 (29), 97 (28), 95 (37), 83 (28), 69 (43), 55 (48). HRMS (EI): calcd. for $\mathrm{C}_{10} \mathrm{H}_{13} \mathrm{O}_{3} \mathrm{~F}_{3}\left[\mathrm{M}^{+}-\mathrm{H}_{2} \mathrm{O}\right] 238.0817$; found 238.0825 .

Diethyl hydroxy(4-hydroxy-2-methylidenebutyl)propanedioate (4e): Colourless oil. $R_{\mathrm{f}}=0.29$ (hexane/EtOAc 1:1); $t_{\mathrm{r}}=13.39 \mathrm{~min} .{ }^{1} \mathrm{H}$ NMR $(400$ $\mathrm{MHz}, \mathrm{CDCl}_{3}$ ): $\delta=5.00\left(\mathrm{~s}, 2 \mathrm{H}, \mathrm{CH}_{2}=\mathrm{C}\right), 4.27$ (q, $J=7.1 \mathrm{~Hz}, 4 \mathrm{H}, 2 \times$ $\mathrm{CH}_{2} \mathrm{CH}_{3}$ ), 3.75 (t, $\left.J=6.0 \mathrm{~Hz}, 2 \mathrm{H}, \mathrm{CH}_{2} \mathrm{OH}\right), 2.84\left(\mathrm{~s}, 2 \mathrm{H}, \mathrm{CCH}_{2} \mathrm{C}\right), 2.39$ (t, $\left.J=6.0 \mathrm{~Hz}, 2 \mathrm{H}, \mathrm{CH}_{2} \mathrm{CH}_{2} \mathrm{O}\right), 1.30\left(\mathrm{t}, J=7.1 \mathrm{~Hz}, 6 \mathrm{H}, 2 \times \mathrm{CH}_{3} \mathrm{CH}_{2}\right) \mathrm{ppm}$.
${ }^{13} \mathrm{C}$ NMR $\left(75 \mathrm{MHz}, \mathrm{CDCl}_{3}\right): \delta=170.1\left(2 \times \mathrm{CO}_{2}\right), 140.8\left(C=\mathrm{CH}_{2}\right), 116.8$ $\left(\mathrm{CH}_{2}=\mathrm{C}\right), 79.4(\mathrm{COH}), 62.5\left(2 \times \mathrm{CH}_{2} \mathrm{CH}_{3}\right), 60.5\left(\mathrm{CH}_{2} \mathrm{OH}\right), 40.1\left(\mathrm{CCH}_{2} \mathrm{C}\right)$, $39.4\left(\mathrm{CH}_{2} \mathrm{CH}_{2} \mathrm{O}\right), 14.0\left(2 \times \mathrm{CH}_{3} \mathrm{CH}_{2}\right)$ ppm. IR $\left(\mathrm{CCl}_{4}\right): v^{\sim}=3496,1739$, $1266,1210 \mathrm{~cm}^{-1}$. MS (EI): $\mathrm{m} / z(\%)=260(<1 \%)\left[\mathrm{M}^{+}\right], 242(3)\left[\mathrm{M}^{+}-\mathrm{H}_{2} \mathrm{O}\right]$, 212 (72), 184 (42), 175 (28), 169 (82), 168 (34), 150 (29), 141 (21), 138 (45), 123 (39), 113 (35), 97 (24), 95 (100), 83 (90), 82 (27), 71 (21), 69 (27), 68 (23), 67 (85), 55 (61), 54 (21). HRMS (EI): calcd. for $\mathrm{C}_{12} \mathrm{H}_{18} \mathrm{O}_{5}$ $\left[\mathrm{M}^{+}-\mathrm{H}_{2} \mathrm{O}\right]$ 242.1154; found 242.1129 .

3-Methylidene-1-(pentafluorophenyl)pentane-1,5-diol (4f): Colourless oil. $R_{\mathrm{f}}=0.23$ (hexane/EtOAc 1:1); $t_{\mathrm{r}}=13.79 \mathrm{~min} .{ }^{1} \mathrm{H}$ NMR $(300 \mathrm{MHz}$, $\left.\mathrm{CDCl}_{3}\right): \delta=5.23(\mathrm{dd}, J=9.0,5.3 \mathrm{~Hz}, 1 \mathrm{H}, \mathrm{CHOH}), 5.01,5.00(2 \mathrm{~s}, 2 \mathrm{H}$, $\mathrm{CH}_{2}=\mathrm{C}$ ), 3.79 (t, $J=6.1 \mathrm{~Hz}, 2 \mathrm{H}, \mathrm{CH}_{2} \mathrm{OH}$ ), $3.35(\mathrm{br} \mathrm{s}, 1 \mathrm{H}, \mathrm{OH}), 2.79$ (dd, $J$ $=14.0,9.0 \mathrm{~Hz}, 1 \mathrm{H}, \mathrm{CHHCH}), 2.52(\mathrm{dd}, J=14.0,5.3 \mathrm{~Hz}, 1 \mathrm{H}, \mathrm{CH} H \mathrm{CH})$, 2.37, $2.34\left(2 \mathrm{dt}, J=14.9,6.1 \mathrm{~Hz}, 2 \mathrm{H}, \mathrm{CH}_{2} \mathrm{CH}_{2} \mathrm{O}\right) \mathrm{ppm} .{ }^{13} \mathrm{C} \mathrm{NMR}(75 \mathrm{MHz}$, $\left.\mathrm{CDCl}_{3}\right): \delta=144.7\left(\mathrm{~d},{ }^{1} J_{\mathrm{C}-\mathrm{F}}=248.2 \mathrm{~Hz}, \mathrm{ArCF}\right), 141.8\left(C=\mathrm{CH}_{2}\right), 140.5(\mathrm{~d}$, $\left.{ }^{1} J_{\mathrm{C}-\mathrm{F}}=253.8 \mathrm{~Hz}, \mathrm{ArCF}\right), 137.5\left(\mathrm{~d},{ }^{1} J_{\mathrm{C}-\mathrm{F}}=253.2 \mathrm{~Hz}, \mathrm{ArCF}\right), 116.6(\mathrm{ArC})$, $115.9\left(\mathrm{CH}_{2}=\mathrm{C}\right), 64.6\left(\mathrm{CHCH}_{2}\right), 60.7\left(\mathrm{CH}_{2} \mathrm{OH}\right), 43.1\left(\mathrm{CH}_{2} \mathrm{CH}\right), 38.3$ $\left(\mathrm{CH}_{2} \mathrm{CH}_{2} \mathrm{O}\right)$ ppm. IR $\left(\mathrm{CCl}_{4}\right): v^{\sim}=3400,1681,1304,1146,1124 \mathrm{~cm}^{-1}$. MS (EI): $m / z(\%)=282(<1 \%)\left[\mathrm{M}^{+}\right], 264$ (4), 246 (38), $234(24), 197$ (100), 181 (37), 169 (29), 68 (30), 67 (30). HRMS (EI): calcd. for $\mathrm{C}_{12} \mathrm{H}_{9} \mathrm{OF}_{5}$ $\left[\mathrm{M}^{+}-\mathrm{H}_{2} \mathrm{O}\right]$ 264.0574; found 264.0574.

3-Methylidene-1-(6-nitro-1,3-benzodioxol-5-yl)pentane-1,5-diol $\quad$ (4g): Yellow oil. $R_{\mathrm{f}}=0.26$ (hexane/EtOAc 1:1). ${ }^{1} \mathrm{H}$ NMR $\left(300 \mathrm{MHz}, \mathrm{CDCl}_{3}\right): \delta=$ 7.49, $7.32(2 \mathrm{~s}, 2 \mathrm{H}, 2 \times \mathrm{ArH}), 6.12,6.11\left(2 \mathrm{~d}, J=1.2 \mathrm{~Hz}, 2 \mathrm{H}, \mathrm{OCH}_{2} \mathrm{O}\right)$, $5.45(\mathrm{dd}, J=9.9,2.4 \mathrm{~Hz}, 1 \mathrm{H}, \mathrm{CHOH}), 5.12,5.09\left(2 \mathrm{~s}, 2 \mathrm{H}, \mathrm{CH}_{2}=\mathrm{C}\right), 3.84(\mathrm{t}$, $\left.J=6.1 \mathrm{~Hz}, 2 \mathrm{H}, \mathrm{CH}_{2} \mathrm{OH}\right), 2.68(\mathrm{~d}, J=13.9 \mathrm{~Hz}, 1 \mathrm{H}, \mathrm{CHHCH}), 2.45(\mathrm{t}, J=$ $6.1 \mathrm{~Hz}, 2 \mathrm{H}, \mathrm{CH}_{2} \mathrm{CH}_{2} \mathrm{OH}$ ), 2.19 (dd, $\left.J=13.9,9.9 \mathrm{~Hz}, 1 \mathrm{H}, \mathrm{CH} H \mathrm{CH}\right) \mathrm{ppm}$. ${ }^{13} \mathrm{C}$ NMR $\left(75 \mathrm{MHz}, \mathrm{CDCl}_{3}\right): \delta=152.4,146.8,143.0,138.1(4 \times \mathrm{ArC})$, $140.9\left(\mathrm{C}=\mathrm{CH}_{2}\right), 115.8\left(\mathrm{CH}_{2}=\mathrm{C}\right), 106.7,105.1(2 \times \mathrm{ArCH}), 102.9\left(\mathrm{OCH}_{2} \mathrm{O}\right)$, $67.7(\mathrm{CHOH}), 60.7\left(\mathrm{CH}_{2} \mathrm{OH}\right), 45.4\left(\mathrm{CH}_{2} \mathrm{CH}\right), 38.2\left(\mathrm{CH}_{2} \mathrm{CH}_{2} \mathrm{OH}\right) \mathrm{ppm}$. IR $\left(\mathrm{CCl}_{4}\right): v^{\sim}=3373,1519,1330,1120,930,760 \mathrm{~cm}^{-1}$. MS (EI-DIP): $\mathrm{m} / z(\%)$ $=263(<1 \%)\left[\mathrm{M}^{+}-\mathrm{H}_{2} \mathrm{O}\right], 230$ (15), 195 (36), 187 (20), 165 (87), 148 (37), 134 (14), 127 (15), 120 (98), 119 (58), 107 (90), 103 (20), 79 (79), 63 (100), 62 (39). HRMS (EI-DIP): calcd. for $\mathrm{C}_{13} \mathrm{H}_{15} \mathrm{NO}_{6}\left[\mathrm{M}^{+}\right]$281.0899; found 281.0915 .

General procedure for the intramolecular acetalisation of homoallylic diols 4: A solution of $\mathrm{PdCl}_{2}(8.9 \mathrm{mg}, 0.05 \mathrm{mmol}), \mathrm{CuCl}_{2}(67.2 \mathrm{mg})$, and the corresponding methylidenic diol $\mathbf{4}(1 \mathrm{mmol})$ in $\mathrm{MeOH}(10 \mathrm{~mL}$, for $\mathbf{4 a}, \mathbf{4 f}$, and $\mathbf{4 g}$ ) or $\mathrm{EtOH}(10 \mathrm{~mL}$, for $\mathbf{4 b}-\mathbf{4 e})$ was prepared in a screw top tube, followed by the addition of a $35 \% \mathrm{H}_{2} \mathrm{O}_{2}$ solution $(0.86 \mathrm{~mL}, 10 \mathrm{mmol})$. The top was airtight on the reaction tube which was heated at $70{ }^{\circ} \mathrm{C}$ for $24 \mathrm{~h}$. After that time, the reaction was monitored by TLC and GLC. One additional portion of $35 \% \mathrm{H}_{2} \mathrm{O}_{2}$ solution $(0.86 \mathrm{~mL}, 10 \mathrm{mmol})$ and heating $\left(70{ }^{\circ} \mathrm{C}\right.$ for $24 \mathrm{~h}$ ) was required for $\mathbf{4 c}, \mathbf{4 e - 4 g}$ (Table 8, entries 3, 5, 6 and 7) and two portions for $\mathbf{4 d}$ (Table 8 , entry 5 ). The solvent was evaporated to dryness, followed by the addition of EtOAc $(20 \mathrm{~mL})$ and filtration through Celite. The filtrate was washed with brine $(2 \times 5 \mathrm{~mL})$, the organic phase was dried over anhydrous $\mathrm{MgSO}_{4}$ and the solvent evaporated under vacuum. The work-up was different for compounds $\mathbf{5 a}, \mathbf{5 b}$, and $\mathbf{5 e}$ : brine $(10 \mathrm{~mL})$ was added to the reaction mixture, followed by extraction with $\mathrm{CH}_{2} \mathrm{Cl}_{2}(3 \times$ $20 \mathrm{~mL}$ ), washing of the organic phase with water $(2 \times 10 \mathrm{~mL})$, and filtration through Celite. The solvent was evaporated under vacuum at $15{ }^{\circ} \mathrm{C}$. All compounds $\mathbf{5}$, except $\mathbf{5 a}$, were purified by column chromatography (silica gel, hexane/EtOAc).

cis-Perhydrofuro[2,3-b]furan (5a): ${ }^{[5 a]}$ Colourless $\quad$ oil. $\quad R_{\mathrm{f}}=0.33$ (hexane/EtOAc 7:3); $t_{\mathrm{r}}=6.89 \mathrm{~min} .{ }^{1} \mathrm{H}$ NMR (300 MHz, $\mathrm{CDCl}_{3}$ ): $\delta=5.68$ (d, $J=5.1 \mathrm{~Hz}, 1 \mathrm{H}$, OCHO), $3.86\left(\mathrm{dd}, J=9.0,5.1 \mathrm{~Hz}, 4 \mathrm{H}, 2 \times \mathrm{CH}_{2} \mathrm{O}\right.$ ), 2.88-2.79 (m, $\left.1 \mathrm{H}, \mathrm{CH}_{2} \mathrm{CHCH}_{2}\right), 2.12-2.04,1.73-1.69(2 \mathrm{~m}, 4 \mathrm{H}$, $\mathrm{CH}_{2} \mathrm{CHCH}_{2}$ ) ppm. ${ }^{13} \mathrm{C}$ NMR (75 MHz, $\mathrm{CDCl}_{3}$ ): $\delta=109.5$ (OCHO), $68.1(2$ 
$\left.\times \mathrm{CH}_{2} \mathrm{O}\right), 42.4\left(\mathrm{CH}_{2} \mathrm{CHCH}_{2}\right), 32.5\left(\mathrm{CH}_{2} \mathrm{CHCH}_{2}\right) \mathrm{ppm}$. IR (film): $v^{\sim}=1055$, $1026 \mathrm{~cm}^{-1}$. MS (EI): $\mathrm{m} / \mathrm{z}(\%)=114(12)\left[\mathrm{M}^{+}\right], 113(30), 84(95), 83$ (32), 69 (49), 68 (68), 67 (68), 57 (13), 56 (46), 55 (100), 54 (26), 53 (25). HRMS (EI): calcd. for $\mathrm{C}_{6} \mathrm{H}_{10} \mathrm{O}_{2}\left[\mathrm{M}^{+}\right]$114.0681; found 114.0687.

$\left(2 R^{*}, 3 a S^{*}, 6 \mathrm{a} R^{*}\right)$-Ethyl perhydrofuro[2,3-b]furan-2-carboxylate $(5 \mathrm{~b})$ : Colourless oil. $R_{\mathrm{f}}=0.59$ (hexane/EtOAc 1:1); $t_{\mathrm{r}}=12.18 \mathrm{~min} .{ }^{1} \mathrm{H}$ NMR $(400$ $\left.\mathrm{MHz}, \mathrm{CDCl}_{3}\right): \delta=5.91(\mathrm{~d}, J=5.0 \mathrm{~Hz}, 1 \mathrm{H}, \mathrm{OCHO}), 4.62(\mathrm{t}, J=7.2 \mathrm{~Hz}, 1$ $\left.\mathrm{H}, \mathrm{OCHCO}_{2}\right), 4.18\left(\mathrm{q}, J=7.2 \mathrm{~Hz}, 2 \mathrm{H}, \mathrm{OCH}_{2} \mathrm{CH}_{3}\right), 3.95-3.84(\mathrm{~m}, 2 \mathrm{H}$, $\left.\mathrm{OCH}_{2} \mathrm{CH}_{2}\right), 2.98-2.84\left(\mathrm{~m}, 1 \mathrm{H}, \mathrm{CH}_{2} \mathrm{CHCH}_{2}\right), 2.25-2.14,2.14-2.00,1.76-$ $1.68\left(3 \mathrm{~m}, 4 \mathrm{H}, \mathrm{CH}_{2} \mathrm{CHCH}_{2}\right), 1.26\left(\mathrm{t}, J=7.2 \mathrm{~Hz}, 3 \mathrm{H}, \mathrm{CH}_{3} \mathrm{CH}_{2} \mathrm{O}\right) \mathrm{ppm} .{ }^{13} \mathrm{C}$ NMR $\left(100 \mathrm{MHz}, \mathrm{CDCl}_{3}\right): \delta=172.1\left(\mathrm{CO}_{2}\right), 110.2(\mathrm{OCHO}), 77.3$ $\left(\mathrm{OCHCO}_{2}\right), 61.3\left(\mathrm{OCH}_{2} \mathrm{CH}_{3}\right), 67.7\left(\mathrm{OCH}_{2} \mathrm{CH}_{2}\right), 41.8\left(\mathrm{CH}_{2} \mathrm{CHCH}_{2}\right), 35.9$, $32.2\left(\mathrm{CH}_{2} \mathrm{CHCH}_{2}\right), 14.2\left(\mathrm{CH}_{3} \mathrm{CH}_{2} \mathrm{O}\right) \mathrm{ppm}$. IR (film): $v^{\sim}=1750,1278,1203$, $1113,1063,1036 \mathrm{~cm}^{-1}$. MS (EI): $\mathrm{m} / z(\%)=186(<1 \%)\left[\mathrm{M}^{+}\right], 113(100), 69$ (89), 66 (17), 55 (30). HRMS (EI): calcd. for $\mathrm{C}_{9} \mathrm{H}_{14} \mathrm{O}_{4}\left[\mathrm{M}^{+}\right]$186.0892; found 186.0895. Selected data for the minor diastereoisomer $\left(2 S^{*}, 3 \mathrm{a} S^{*}, 6 \mathrm{a} R^{*}\right)-\mathbf{5 b}: t_{\mathrm{r}}=11.98 \mathrm{~min} .{ }^{1} \mathrm{H} \mathrm{NMR}\left(400 \mathrm{MHz}, \mathrm{CDCl}_{3}\right): \delta=5.77(\mathrm{~d}$, $J=5.2 \mathrm{~Hz}, 1 \mathrm{H}, \mathrm{OCHO}), 4.44\left(\mathrm{dd}, J=8.3,6.7 \mathrm{~Hz}, 1 \mathrm{H}, \mathrm{OCHCO}_{2}\right), 2.55-$ 2.44, 2.14-2.00, 1.99-1.89, 1.76-1.68 (4 m, $\left.4 \mathrm{H}, \mathrm{CH}_{2} \mathrm{CHCH}_{2}\right)$ ppm. MS $(\mathrm{EI}): m / z(\%)=186(<1 \%)\left[\mathrm{M}^{+}\right], 113(100), 69(91), 67(17), 55(31)$.

$\left(2 S^{*}, 3 \mathrm{a} S^{*}, 6 \mathrm{a} R^{*}\right)$-Ethyl 2-methylperhydrofuro[2,3-b]furan-2-carboxylate (5c): Colourless oil. $R_{\mathrm{f}}=0.54$ (hexane/EtOAc 1:1); $t_{\mathrm{r}}=11.68 \mathrm{~min} .{ }^{1} \mathrm{H}$ NMR (400 MHz, $\left.\mathrm{CDCl}_{3}\right): \delta=5.79(\mathrm{~d}, J=5.1 \mathrm{~Hz}, 1 \mathrm{H}, \mathrm{OCHO}), 4.22(\mathrm{q}, J=7.1$ $\left.\mathrm{Hz}, 2 \mathrm{H}, \mathrm{OCH}_{2} \mathrm{CH}_{3}\right), 3.91-3.78\left(\mathrm{~m}, 2 \mathrm{H}, \mathrm{OCH}_{2} \mathrm{CH}_{2}\right), 3.01-2.86(\mathrm{~m}, 1 \mathrm{H}$, $\mathrm{CH}_{2} \mathrm{CHCH}_{2}$ ), 2.42-2.33, 2.11-1.99, 1.76-1.67 (3 m, $4 \mathrm{H}, \mathrm{CH}_{2} \mathrm{CHCH}_{2}$ ), 1.45 (s, $3 \mathrm{H}, \mathrm{CH}_{3} \mathrm{C}$ ), 1.30 (t, $\left.J=7.1 \mathrm{~Hz}, 3 \mathrm{H}, \mathrm{CH}_{3} \mathrm{CH}_{2} \mathrm{O}\right) \mathrm{ppm} .{ }^{13} \mathrm{C} \mathrm{NMR}$ $\left(100 \mathrm{MHz}, \mathrm{CDCl}_{3}\right): \delta=174.6\left(\mathrm{CO}_{2}\right), 110.4(\mathrm{OCHO}), 84.7\left(\mathrm{CCH}_{3}\right), 67.2$ $\left(\mathrm{OCH}_{2} \mathrm{CH}_{2}\right), 61.4\left(\mathrm{OCH}_{2} \mathrm{CH}_{3}\right), 42.9\left(\mathrm{CH}_{2} \mathrm{CHCH}_{2}\right), 41.1,32.0\left(\mathrm{CH}_{2} \mathrm{CHCH}_{2}\right)$ $23.9\left(\mathrm{CH}_{3} \mathrm{C}\right), 14.3\left(\mathrm{CH}_{3} \mathrm{CH}_{2} \mathrm{O}\right) \mathrm{ppm}$. IR (film): $v^{\sim}=1731,1286,1184,1129$, $1017 \mathrm{~cm}^{-1}$. MS (EI): $\mathrm{m} / z(\%)=156(1)\left[\mathrm{M}^{+}-\mathrm{CO}_{2}\right], 127$ (100), 85 (15), 83 (11), 81 (9). HRMS (EI): calcd. for $\mathrm{C}_{10} \mathrm{H}_{16} \mathrm{O}_{4}\left[\mathrm{M}^{+}\right]$200.1049; found 200.1048. Selected data for the minor diastereoisomer $\left(2 R^{*}, 3 \mathrm{a} S^{*}, 6 \mathrm{a} R^{*}\right)-\mathbf{5} \mathbf{c}: t_{\mathrm{r}}$ $=11.82 \mathrm{~min} .{ }^{1} \mathrm{H}$ NMR $\left(400 \mathrm{MHz}, \mathrm{CDCl}_{3}\right): \delta=5.87(\mathrm{~d}, J=5.3 \mathrm{~Hz}, 1 \mathrm{H}$, OCHO), 4.18 (q, $\left.J=6.8 \mathrm{~Hz}, 2 \mathrm{H}, \mathrm{OCH}_{2} \mathrm{CH}_{3}\right), 2.57-2.49,2.08-1.89,1.76-$ 1.67 (3 m, $4 \mathrm{H}, \mathrm{CH}_{2} \mathrm{CHCH}_{2}$ ), 1.55 (s, $3 \mathrm{H}, \mathrm{CH}_{3} \mathrm{C}$ ) ppm. $\mathrm{MS}(\mathrm{EI}): \mathrm{m} / z(\%)=$ $156(1)\left[\mathrm{M}^{+}-\mathrm{CO}_{2}\right], 127$ (100), 85 (15), 83 (9), 81 (10).

$\left(2 S^{*}, 3 a S^{*}, 6 a R^{*}\right)$-Ethyl $\quad$ 2-(trifluoromethyl)perhydrofuro[2,3-b]furan-2carboxylate (5d): Colourless oil. $R_{\mathrm{f}}=0.55$ (hexane/EtOAc 3:1); $t_{\mathrm{r}}=10.48$ $\min .{ }^{1} \mathrm{H}$ NMR $\left(400 \mathrm{MHz}, \mathrm{CDCl}_{3}\right): \delta=5.95(\mathrm{~d}, J=5.0 \mathrm{~Hz}, 1 \mathrm{H}, \mathrm{OCHO})$, $4.32\left(\mathrm{q}, J=7.0 \mathrm{~Hz}, 2 \mathrm{H}, \mathrm{OCH}_{2} \mathrm{CH}_{3}\right), 4.04-3.92\left(\mathrm{~m}, 2 \mathrm{H}, \mathrm{OCH}_{2} \mathrm{CH}_{2}\right), 3.10$ $2.97\left(\mathrm{~m}, 1 \mathrm{H}, \mathrm{CH}_{2} \mathrm{CHCH}_{2}\right), 2.73-2.65,2.30-1.99,1.77-1.68(3 \mathrm{~m}, 4 \mathrm{H}$, $\left.\mathrm{CH}_{2} \mathrm{CHCH}_{2}\right), 1.33$ (t, $\left.J=7.0 \mathrm{~Hz}, 3 \mathrm{H}, \mathrm{CH}_{3} \mathrm{CH}_{2} \mathrm{O}\right) \mathrm{ppm} .{ }^{13} \mathrm{C}$ NMR $(100$ $\left.\mathrm{MHz}, \mathrm{CDCl}_{3}\right): \delta=169.2\left(\mathrm{CO}_{2}\right), 127.2\left(\mathrm{CF}_{3}\right), 112.9(\mathrm{OCHO}), 84.7\left(\mathrm{CCF}_{3}\right)$, $67.1\left(\mathrm{OCH}_{2} \mathrm{CH}_{2}\right), 62.9\left(\mathrm{OCH}_{2} \mathrm{CH}_{3}\right), \quad 42.6\left(\mathrm{CH}_{2} \mathrm{CHCH}_{2}\right), \quad 36.1, \quad 32.6$ $\left(\mathrm{CH}_{2} \mathrm{CHCH}_{2}\right), 14.1\left(\mathrm{CH}_{3} \mathrm{CH}_{2} \mathrm{O}\right) \mathrm{ppm}$. IR (film): $v^{\sim}=1745,1244,1177 \mathrm{~cm}^{-1}$ MS (EI): $m / z(\%)=254(<1 \%)\left[\mathrm{M}^{+}\right], 182(8), 181$ (100), 164 (5), 135 (7), 115 (10), 83 (5), 69 (7), 55 (7). HRMS (EI): calcd. for $\mathrm{C}_{10} \mathrm{H}_{13} \mathrm{O}_{4} \mathrm{~F}_{3}\left[\mathrm{M}^{+}\right]$ 254.0766; found 254.0767. Selected data for the minor diastereoisomer $\left(2 R^{*}, 3 \mathrm{a} S^{*}, 6 \mathrm{a} R^{*}\right)-5 \mathrm{~d}: t_{\mathrm{r}}=10.74 \mathrm{~min} .{ }^{1} \mathrm{H}$ NMR $\left(400 \mathrm{MHz}, \mathrm{CDCl}_{3}\right): \delta=6.02$ $(\mathrm{d}, J=4.9 \mathrm{~Hz}, 1 \mathrm{H}, \mathrm{OCHO}) \mathrm{ppm}$. MS (EI): $\mathrm{m} / z(\%)=254(<1 \%)\left[\mathrm{M}^{+}\right], 182$ (7), 181 (100), 135 (6), 115 (8), 69 (5).

$\left(3 a S^{*}, 6 a R^{*}\right)$-Diethyl perhydrofuro[2,3-b]furan-2,2-dicarboxylate (5e): Colourless oil. $R_{\mathrm{f}}=0.48$ (hexane/EtOAc 8:2); $t_{\mathrm{r}}=14.68 \mathrm{~min} .{ }^{1} \mathrm{H}$ NMR $(400$ $\left.\mathrm{MHz}, \mathrm{CDCl}_{3}\right): \delta=5.97$ (d, $\left.J=5.2 \mathrm{~Hz}, 1 \mathrm{H}, \mathrm{OCHO}\right), 4.38-4.14(\mathrm{~m}, 4 \mathrm{H}, 2 \times$ $\left.\mathrm{OCH}_{2} \mathrm{CH}_{3}\right), 4.02-3.83\left(\mathrm{~m}, 2 \mathrm{H}, \quad \mathrm{OCH}_{2} \mathrm{CH}_{2}\right), 3.07-2.88(\mathrm{~m}, 1 \mathrm{H}$, $\mathrm{CH}_{2} \mathrm{CHCH}_{2}$ ), 2.60 (dd, $\left.J=13.8,9.6 \mathrm{~Hz}, 1 \mathrm{H}, \mathrm{CH} H \mathrm{C}\right), 2.42(\mathrm{dd}, J=13.8$, $6.6 \mathrm{~Hz}, 1 \mathrm{H}, \mathrm{CHHC}$ ), 2.02 (ddt, $J=12.6,10.8,8.3 \mathrm{~Hz}, 1 \mathrm{H}, \mathrm{CHHCH}_{2} \mathrm{O}$ ), 1.77 (ddt, $J=12.6,5.4,1.6 \mathrm{~Hz}, 1 \mathrm{H}, \mathrm{CHHCH}_{2} \mathrm{O}$ ), $1.28(\mathrm{t}, J=7.1 \mathrm{~Hz}, 3 \mathrm{H}$, $\left.\mathrm{CH}_{3} \mathrm{CH}_{2} \mathrm{O}\right), 1.26\left(\mathrm{t}, J=7.1 \mathrm{~Hz}, 3 \mathrm{H}, \mathrm{CH}_{3} \mathrm{CH}_{2} \mathrm{O}\right) \mathrm{ppm} .{ }^{13} \mathrm{C} \mathrm{NMR}(100 \mathrm{MHz}$,
$\left.\mathrm{CDCl}_{3}\right): \delta=169.8,168.4\left(2 \times \mathrm{CO}_{2}\right), 111.7(\mathrm{OCHO}), 87.2\left(\mathrm{CCO}_{2}\right), 67.1$ $\left(\mathrm{OCH}_{2} \mathrm{CH}_{2}\right), 62.3,62.2\left(2 \times \mathrm{CH}_{2} \mathrm{CH}_{3}\right), 42.3\left(\mathrm{CH}_{2} \mathrm{CHCH}_{2}\right), 37.6,32.2$ $\left(\mathrm{CH}_{2} \mathrm{CHCH}_{2}\right), 14.2,14.1\left(2 \times \mathrm{CH}_{3} \mathrm{CH}_{2}\right)$ ppm. IR (film): $v^{\sim}=1742,1283$, 1238, 1118, 1064, $1027 \mathrm{~cm}^{-1}$. MS (EI): $\mathrm{m} / z(\%)=258(<1 \%)\left[\mathrm{M}^{+}\right], 186$ (11), 185 (100), 139 (11), 129 (12), 111 (15), 83 (44), 55 (12). HRMS (EI): calcd. for $\mathrm{C}_{12} \mathrm{H}_{18} \mathrm{O}_{6}\left[\mathrm{M}^{+}\right]$258.1103; found 258.1073.

$\left(2 R^{*}, 3 \mathrm{a} S^{*}, 6 \mathrm{a} R^{*}\right)$-2-(Pentafluorophenyl)perhydrofuro[2,3-b] furan (5f): Colourless oil. $R_{\mathrm{f}}=0.62$ (hexane/EtOAc 1:1); $t_{\mathrm{r}}=13.33 \mathrm{~min} .{ }^{1} \mathrm{H}$ NMR (400 $\mathrm{MHz}, \mathrm{CDCl}_{3}$ ): $\delta=5.91$ (d, $\left.J=4.9 \mathrm{~Hz}, 1 \mathrm{H}, \mathrm{OCHO}\right), 5.47$ (dd, $J=9.5,6.9$ $\mathrm{Hz}, 1 \mathrm{H}, \mathrm{OCHAr}), 4.09-3.95\left(\mathrm{~m}, 2 \mathrm{H}, \mathrm{OCH}_{2} \mathrm{CH}_{2}\right), 3.19-3.09(\mathrm{~m}, 1 \mathrm{H}$, $\mathrm{CH}_{2} \mathrm{CHCH}_{2}$ ), 2.48-2.33, 2.27-2.11, 1.88-1.79 (3 m, 4 H, $\mathrm{CH}_{2} \mathrm{CHCH}_{2}$ ) ppm. ${ }^{13} \mathrm{C} \mathrm{NMR}\left(100 \mathrm{MHz}, \mathrm{CDCl}_{3}\right): \delta=145.4\left(\mathrm{~d},{ }^{1} J_{\mathrm{C}-\mathrm{F}}=253.6 \mathrm{~Hz}, \mathrm{ArCF}\right), 141.1$ $\left(\mathrm{d},{ }^{1} J_{\mathrm{C}-\mathrm{F}}=260.7 \mathrm{~Hz}, \mathrm{ArCF}\right), 137.8\left(\mathrm{~d},{ }^{1} J_{\mathrm{C}-\mathrm{F}}=254.0 \mathrm{~Hz}, \mathrm{ArCF}\right), 114.8(\mathrm{ArC})$, 110.0 (OCHO), 71.6 (OCHAr), $68.2\left(\mathrm{OCH}_{2} \mathrm{CH}_{2}\right), 43.3\left(\mathrm{CH}_{2} \mathrm{CHCH}_{2}\right), 38.4$, $32.5\left(\mathrm{CH}_{2} \mathrm{CHCH}_{2}\right) \mathrm{ppm}$. IR (film): $v^{\sim}=1737,1655,1524,1506,1132,1020$ $\mathrm{cm}^{-1}$. MS (EI): $m / z(\%)=280(3)\left[\mathrm{M}^{+}\right], 235$ (12), 234 (43), 233 (11), 219 (83), 214 (11), 207 (15), 195 (33), 194 (66), 193 (10), 187 (23), 181 (73), 169 (17), 167 (11), 143 (11), 84 (100), 83 (24), 69 (20), 56 (22), 55 (36), 54 (12). HRMS (EI): calcd. for $\mathrm{C}_{12} \mathrm{H}_{9} \mathrm{~F}_{5} \mathrm{O}_{2}\left[\mathrm{M}^{+}\right] 280.0523$, found 280.0519 . Selected data for the minor diastereoisomer $\left(2 S^{*}, 3 \mathrm{a} S^{*}, 6 \mathrm{a} R^{*}\right)-\mathbf{5 f}: t_{\mathrm{r}}=13.43$ $\min .{ }^{1} \mathrm{H}$ NMR (400 MHz, $\left.\mathrm{CDCl}_{3}\right): \delta=5.75(\mathrm{~d}, J=5.5 \mathrm{~Hz}, 1 \mathrm{H}$, OCHO), $5.10(\mathrm{dd}, J=11.2,5.8 \mathrm{~Hz}, 1 \mathrm{H}, \mathrm{OCH} \mathrm{Ar}), 3.08-2.98\left(\mathrm{~m}, 1 \mathrm{H}, \mathrm{CH}_{2} \mathrm{CHCH}_{2}\right)$ ppm. ${ }^{13} \mathrm{C}$ NMR (100 MHz, $\mathrm{CDCl}_{3}$ ): $\delta=109.3$ (OCHO), 70.7 (OCHAr), $66.5\left(\mathrm{OCH}_{2} \mathrm{CH}_{2}\right), 43.4\left(\mathrm{CH}_{2} \mathrm{CHCH}_{2}\right), 36.2,32.6\left(\mathrm{CH}_{2} \mathrm{CHCH}_{2}\right)$ ppm. MS $(\mathrm{EI}): \mathrm{m} / \mathrm{z}(\%)=280(<1 \%)\left[\mathrm{M}^{+}\right], 234(15), 219(43), 195(27), 194(42)$, 187 (15), 181 (47), 169 (11), 84 (100), 83 (22), 69 (16), 56 (19), 55 (31), 54 (11).

5-[(2 $\left.R^{*}, 3 \mathrm{a} S^{*}, 6 \mathrm{a} R^{*}\right)$-perhydrofuro[2,3-b]furan-2-yl]-6-nitro-1,3-

benzo[d][1,3]dioxole (5g): Yellow oil. $R_{\mathrm{f}}=0.64$ (hexane/EtOAc 1:1); $t_{\mathrm{r}}=$ $20.46 \mathrm{~min} .{ }^{1} \mathrm{H}$ NMR $\left(400 \mathrm{MHz}, \mathrm{CDCl}_{3}\right): \delta=7.52,7.25(2 \mathrm{~s}, 2 \mathrm{H}, 2 \times \mathrm{ArH})$, $6.11\left(\mathrm{~d}, J=3.0 \mathrm{~Hz}, 2 \mathrm{H}, \mathrm{OCH}_{2} \mathrm{O}\right), 5.97(\mathrm{~d}, J=5.0 \mathrm{~Hz}, 1 \mathrm{H}, \mathrm{OCHO}), 5.65$ (dd, $J=9.6,5.6 \mathrm{~Hz}, 1 \mathrm{H}, \mathrm{OCHAr}$ ), 4.08-3.94 (m, $2 \mathrm{H}, \mathrm{OCH}_{2} \mathrm{CH}_{2}$ ), 3.052.95 (m, $1 \mathrm{H}, \mathrm{CH}_{2} \mathrm{CHCH}_{2}$ ), 2.60-2.51, 2.25-2.13, 1.96-1.88, 1.88-1.78 (4 $\left.\mathrm{m}, 4 \mathrm{H}, \mathrm{CH}_{2} \mathrm{CHCH}_{2}\right)$ ppm. ${ }^{13} \mathrm{C} \mathrm{NMR}\left(100 \mathrm{MHz}, \mathrm{CDCl}_{3}\right): \delta=152.7,147.1$, 141.3, $136.2(4 \times \mathrm{ArC}), 109.5$ (OCHO), 106.3, $105.4(2 \times \mathrm{ArCH}), 103.1$ $\left(\mathrm{OCH}_{2} \mathrm{O}\right), 77.5$ (OCHAr), $68.1\left(\mathrm{OCH}_{2} \mathrm{CH}_{2}\right), 43.1\left(\mathrm{CH}_{2} \mathrm{CHCH}_{2}\right), 41.0,32.4$ $\left(\mathrm{CH}_{2} \mathrm{CHCH}_{2}\right)$ ppm. IR (ATR): $v^{\sim}=3018,2853,1512,1482,1257,1150$, $1019 \mathrm{~cm}^{-1}$. MS (EI): $\mathrm{m} / \mathrm{z}(\%)=262(6)\left[\mathrm{M}^{+}-\mathrm{OH}\right], 216(28), 206(12), 190$ (10), 187 (12), 178 (11), 177 (10), 176 (17), 174 (11), 164 (15), 163 (12), 149 (14), 148 (21), 136 (22), 135 (16), 120 (22), 119 (11), 115 (10), 84 (17), 83 (100), 79 (13), 77 (13), 70 (12), 69 (20), 65 (12), 63 (19), 62 (12), 56 (17), 55 (45), 54 (11), 53 (15), 51 (10). HRMS (EI): calcd. for $\mathrm{C}_{13} \mathrm{H}_{13} \mathrm{NO}_{6}$ $\left[\mathrm{M}^{+}\right]$279.0743; found 279.0765. Selected data for the minor diastereoisomer $\left(2 S^{*}, 3 \mathrm{a} S^{*}, 6 \mathrm{a} R^{*}\right)-\mathbf{5 g}: t_{\mathrm{r}}=20.14 \mathrm{~min} .{ }^{1} \mathrm{H}$ NMR $(400 \mathrm{MHz}$, $\left.\mathrm{CDCl}_{3}\right): \delta=5.82(\mathrm{~d}, J=4.9 \mathrm{~Hz}, 1 \mathrm{H}, \mathrm{OCHO}), 5.50(\mathrm{dd}, J=9.2,6.2 \mathrm{~Hz}, 1$ $\mathrm{H}, \mathrm{OCH} \mathrm{Ar}) \mathrm{ppm}$. MS (EI): $m / z(\%)=262(5)\left[\mathrm{M}^{+}-\mathrm{OH}\right], 217(10), 216(23)$, 206 (10), 191 (11), 190 (11), 188 (11), 187 (11), 178 (11), 177 (10), 176 (19), 174 (12), 165 (11), 149 (15), 148 (17), 136 (20), 135 (23), 121 (10), 120 (18), 115 (12), 89 (11), 84 (31), 83 (100), 77 (15), 70 (11), 69 (18), 65 (13), 63 (18), 62 (15), 56 (15), 55 (37), 54 (10), 53 (14), 51 (10).

\section{Acknowledgments}

This work was generously supported by the Spanish Ministerio de Ciencia e Innovación (MICINN; CTQ2007-65218 and Consolider Ingenio 2010CSD2007-00006), the Generalitat Valenciana (GV; PROMETEO/2009/039), and FEDER. D. S. thanks the Vicerrectorado de Investigación, Desarrollo e Innovación of the Universidad de Alicante for a predoctoral grant. M. R.-F. thanks the ISO of the Universidad de Alicante for a postdoctoral grant. 
[1] For some recent examples, see for instance: a) X.-C. Huang, S. Qin, Y.-W. Guo, K. Krohn, Helv. Chim. Acta 2008, 91, 628-634; b) X.-F Wu, Y.-C. Hu, S.-S. Yu, N. Jiang, J. Ma, R.-X. Tan, Y. Li, H.-N Lv, J. Liu, S.-G. Ma, Org. Lett. 2010, 12, 2390-2393.

[2] See, for instance: a) H. Chen, R. X. Tan, Z. L. Liu, Y. Zhang, J. Nat. Prod. 1996, 59, 668-670; b) I. M. Boneva, P. Y. Malakov, G. Y. Papanov, Phytochemistry 1998, 47, 303-305; c) P. Y. Malakov, G. Y. Papanov, Phytochemistry 1998, 49, 2443-2447.

[3] See, for instance: a) P. Y. Malakov, G. Y. Papanov, I. M. Boneva, Phytochemistry 1996, 41, 855-857; b) M. C. de la Torre, B Rodríguez, B. Bruno, N. Vassallo, M. L. Bondì, F. Piozzi, O. Servettaz, J. Nat. Prod. 1997, 60, 1229-1235; c) P. Y. Malakov, G. Y. Papanov, Phytochemistry 1997, 46, 955-958; d) P. Y. Malakov, G. Y. Papanov, V. B. Deltchev, Phytochemistry 1998, 49, 811-815.

[4] For a review, see: a) E. A. klein Gebbinck, B. J. M. Jansen, A. de Groot, Phytochemistry 2002, 61, 737-770; see also: b) S. Rosselli, A Maggio, F. Piozzi, M. S. J. Simmonds, M. Bruno, M. J. Agric. Food Chem. 2004, 52, 7867-7871, and references cited therein.

[5] a) J. Vader, H. Sengers, A. de Groot, Tetrahedron 1989, 45, 2131 2142 ; b) E. A. klein Gebbinck, C. T. Bouwman, M. Bourgois, B. J. M. Jansen, A. de Groot, Tetrahedron 1999, 55, 11051-11076.

[6] a) F. Kido, S. C. Sinha, T. Abiko, M. Watanabe, A. Yoshikoshi, J. Chem. Soc., Chem. Commun. 1990, 418-420; b) F. Kido, S. C. Sinha, T. Abiko, M. Watanabe, A. Yoshikoshi, Tetrahedron 1990, 46, 4887-4906.

[7] a) F. Alonso, E. Lorenzo, M. Yus, Tetrahedron Lett. 1997, 38, $2187-$ 2190; b) F. Alonso, E. Lorenzo, M. Yus, Tetrahedron Lett. 1998, 39 , 3303-3306; c) E. Lorenzo, F. Alonso, M. Yus, Tetrahedron Lett. 2000, 41, 1661-1665; d) E. Lorenzo, F. Alonso, M. Yus, Tetrahedron 2000, 56, 1745-1757; e) F. Alonso, E. Lorenzo, J. Meléndez, M. Yus, Tetrahedron 2003, 59, 5199-5208; f) F. Alonso, J. Meléndez, M. Yus, Russ. Chem. Bull. 2003, 52, 2628-2576; g) F Alonso, J. Meléndez, M. Yus, Tetrahedron Lett. 2005, 46, 65196524; h) F. Alonso, J. Meléndez, M. Yus, Tetrahedron 2006, 62, 4814-4822.

[8] a) F. Alonso, L. R. Falvello, P. E. Fanwick, E. Lorenzo, M. Yus, Synthesis 2000, 949-952; b) F. Alonso, J. Meléndez, M. Yus, Helv. Chim. Acta 2002, 85, 3262-3271; c) F. Alonso, J. Meléndez, M. Yus, Tetrahedron Lett. 2004, 45, 1717-1720; d) F. Alonso, B. Dacunha, J. Meléndez, M. Yus, Tetrahedron 2005, 61, 3437-3450; e) B. Dacunha, F. Alonso, J. Meléndez, M. Yus, Acta Cryst. 2005, A61, C157; f) J. Meléndez, F. Alonso, M. Yus, Tetrahedron Lett. 2006, 47, 1187-1191; g) F. Alonso, J. Meléndez, T. Soler, M. Yus, Tetrahedron 2006, 62, 2264-2277; h) F. Alonso, F. Foubelo, M. Yus, Curr. Chem. Biol. 2007, 1, 317-346; i) F. Alonso, J. Meléndez, M. Yus, Synlett 2008, 1627-1430.

[9] Alonso, F.; Sánchez, D.; Yus, M. Adv. Synth. Catal. 2008, 350, 2118-2126.

[10] F. Alonso, M. Rodríguez-Fernández, D. Sánchez, M. Yus, Synthesis 2010, 3013-3020

[11] For reviews, see: a) K. Mikami, M. Shimizu, Chem. Rev. 1992, 92 1021-1050; b) M. L. Clarke, M. B. France, Tetrahedron 2008, 64,
9003-9031; c) V. Caprio, J. M. J. Williams, Catalysis in Asymmetric Synthesis, Wiley-Blackwell, Hoboken, 2008, pp. 203-208.

[12] For recent examples, see for instance: a) K. Zheng, J. Shi, X. Liu, X Feng, J. Am. Chem. Soc. 2008, 130, 15770-15771; b) H.-K. Luo, Y.L. Woo, H. Schumann, C. Jacob, M. van Meurs, H.-Y. Yang, Y.-T. Tan, Adv. Synth. Catal. 2010, 352, 1356-1364.

[13] a) K. Mikami, M. Shimizu, T. Nakai, J. Org. Chem. 1991, 56, 29522953; b) K. Mikami, H. Ohmura, M. Yamanaka, J. Org. Chem. 2003, 68, 1081-1088; c) R. Kolodziuk, C. Goux-Henry, D. Sinou, Tetrahedron: Asymmmetry 2007, 18, 2782-2786.

[14] D. A. Evans, S. W. Tregay, C. S. Burgey, N. A. Paras, T. Vojkovsky, J. Am. Chem. Soc. 2000, 122, 7936-7943.

[15] For reviews, see: a) J. Tsuji, in Comprehensive Organic Synthesis, Vol. 7 (Eds.: B. M. Trost, I. F. Fleming, S. V. Ley), Pergamon, Oxford, UK, 1991, Chapter 3.4; b) P. M. Henry, in Handbook of Organopalladium Chemistry for Organic Synthesis, Vol. 2 (Ed.: E. Negishi), Wiley-Interscience, Hoboken, USA, 2002, Chapter V.3; c) J. Muzart, Tetrahedron 2007, 63, 7505-7521; d) J. A. Keith, P. M. Henry, Angew. Chem. Int. Ed. 2009, 48, 9038-9049.

[16] See, for instance: a) J. Tateiwa, A. Kimura, M. Takasuka, S. Uemura J. Chem. Soc., Perkin Trans. 1 1997, 2169-2174; b) T. M. Jyothi, M. L. Kaliya, M. V. Landau, Angew. Chem. Int. Ed. 2001, 40, 28812884; c) T. Okachi, K. Fujimoto, M. Onaka, Org. Lett. 2002, 4, 1667-1669; d) T. Okachi, M. Onaka, J. Am. Chem. Soc. 2004, 126 , 2306-2307.

[17] B. B. Snider, D. J. Rodini, T. C. Kirk, R. Cordova, J. Am. Chem. Soc. 1982, 104, 555-563.

[18] a) J. Hao, M. Hatano, K. Mikami, Org. Lett. 2000, 2, 4059-4062; b) H.-K. Luo, H.-Y. Yang, T.-X. Jie, O. S. Chiew, H. Schumann, L. B Khim, C. Lim, J. Mol. Catal. A: Chem. 2007, 261, 112-119.

[19] For a detailed study, see: M. F. Salomon, S. N. Pardo, R. G. Salomon, J. Am. Chem. Soc. 1984, 106, 3797-3802.

[20] E. J. Corey, A. Venkateswarlu, J. Am. Chem. Soc. 1972, 94, 61906191.

[21] R. Roggenbuck, A. Schmidt, P. Eilbracht, Org. Lett. 2002, 4, 289291.

[22] Stewart, J. J. P. J. Comp. Chem. 1991, 12, 320-341.

[23] For reviews, see: a) T. Hosokawa, S.-I. Murahashi, in Handbook of Organopalladium Chemistry for Organic Synthesis, Vol. 2 (Ed.: E. Negishi), Wiley-Interscience, Hoboken, USA, 2002, Chapter V.3.2; b) J. Muzart, Tetrahedron 2005, 61, 5955-6008; c) J. Muzart, J. Mol. Catal. A: Chem. 2010, 319, 1-29.

[24] K. Mikami, T.-P. Loh, T. Nakai, Tetrahedron Lett. 1988, 29, 63056308 .

Received: ((will be filled in by the editorial staff)) Published online: ((will be filled in by the editorial staff)) 


\section{Entry for the Table of Contents}

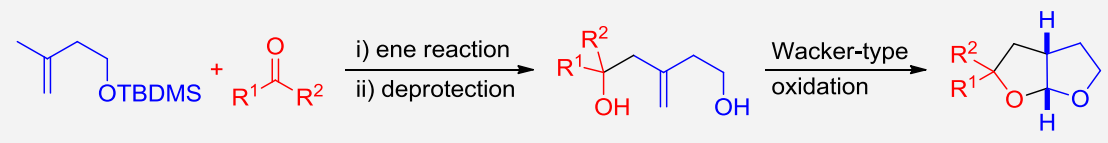

A new synthetic approach toward the synthesis of perhydrofuro[2,3-b]furans is described. The strategy is based on the carbonyl-ene reaction of protected isopentenyl alcohol with several activated enophiles, followed by deprotection and palladium-catalysed intramolecular acetalisation.
Francisco Alonso,* Mamen RodríguezFernández, Daniel Sánchez and Miguel Yus* Page No. - Page No.

Synthesis of Perhydrofuro[2,3-b]furans from Isopentenyl Alcohol through Carbonyl-ene and Wacker-type Reactions

Keywords: Lewis acids/Ene reaction/ Oxidation/Wacker/Perhydrofurofuran 